\title{
التوحد لدى الأطفال
}

\author{
إعراد \\ الباحثة/ شرين البلدراوي عبد التواب السعيد
}

اشراف

أ . د / حسين محمد سعلداللين الحسيني

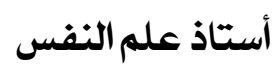

بكليت الآداب - جامعت المنصورة

المجلت العلميت لكليت رياض الأطفال ـ جامعت المنصورة

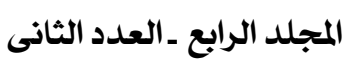

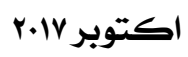




\section{العلاج المعرفي السلوكي لدى الأطفال}

شرين البدراوى عبد التواب السعيد*

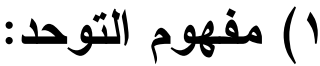

تعددت التعريفات واختلفت في تعريف الطفل التوحدي فهنالك مصطلحات عدة استخدمها الباحثون للإثشارة إلى الاضطر اب التوحدي متل : ذهان الطفولــــة،

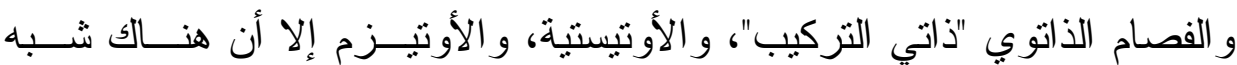

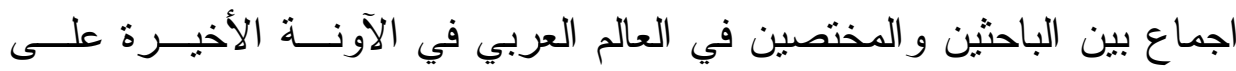
استخدام مصطلح التوحد حيث إن هناك تعدد المسميات قد يؤدي إلــى التــداخل

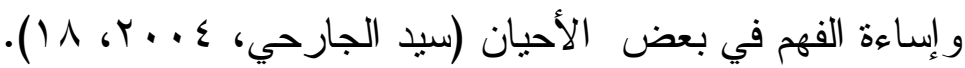
ويعرف الدليل الاحصائي الخامس للاضطر ابات العقلية (الهـصـادر عـن رابطة الطبيب النفسي الأمريكي) التوحد بأنه عجز ثابت في التو اصل و التفاعـلــل الاجتماعي في سياقات متعددة في الفترة الر اهنة وتتشمل كل من الانتباه، الإدر الك

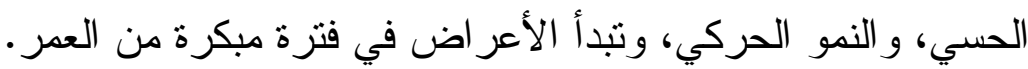
فالتوحد هو إعاقة تطورية تؤثر في جميع قدرات الطفل خاصة القـدرات الاجتماعية و التو اصل اللفظي، وكذلك في الأطفال الذين ليس لديهم تو اصل لفظي

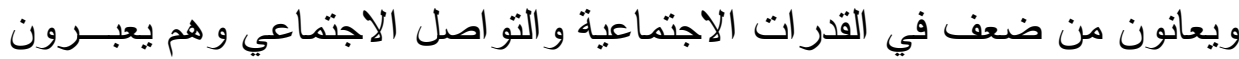
عن ذللك من خلال سلوك العنف الذي ينشأ لاى البعض منهم (باتريـشـا هــاولن

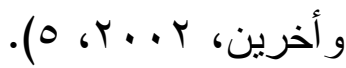


وتعرف (ماريكا Marical، ، 999 (19) التوحد بأنه زملة أعر اض سـلوكيو

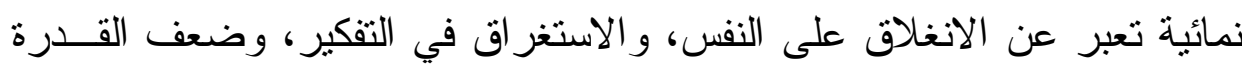

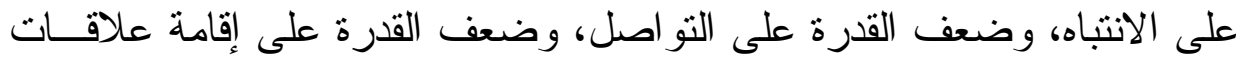

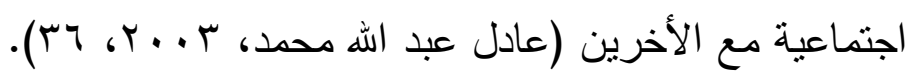

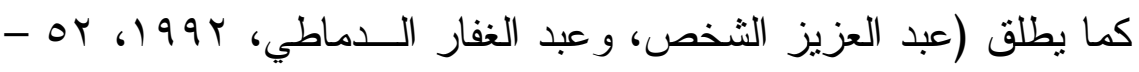

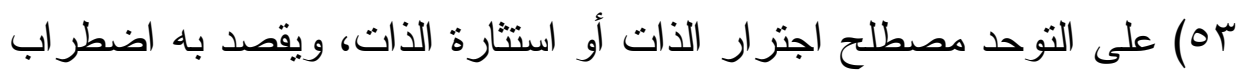

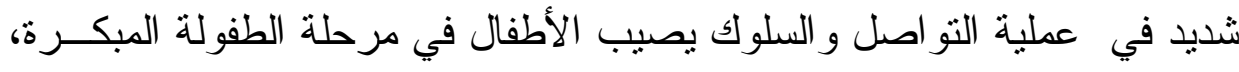

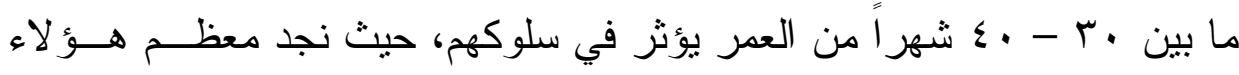

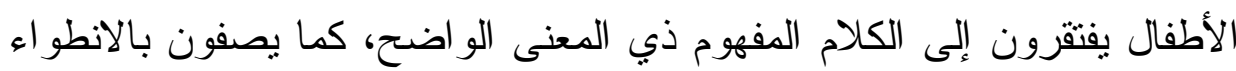

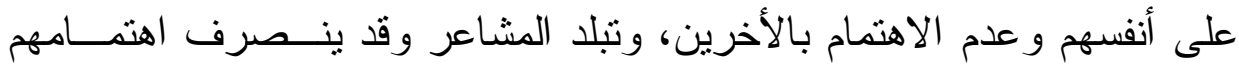
أحياناً إلى الحيو انات أو الأثياء غير الإنسانية ويلتصقون بهاء..

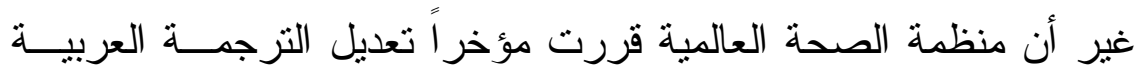

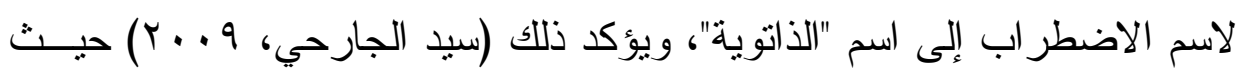
يؤكد أن النوحد معناه أن يتقص الثخص مشاعر الأخر وتفكيرهوسلوكه، وهذا

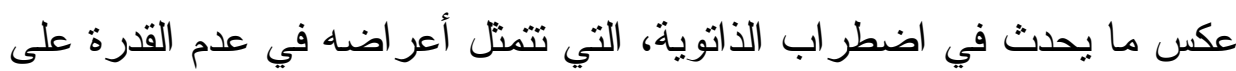

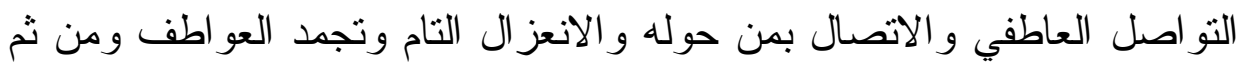

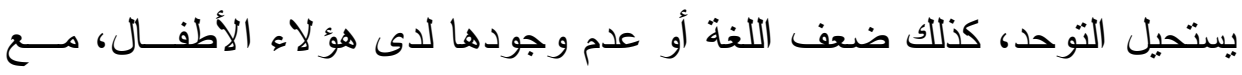

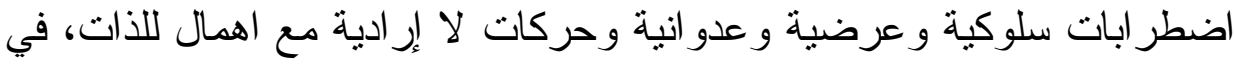

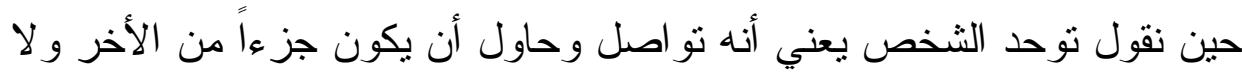

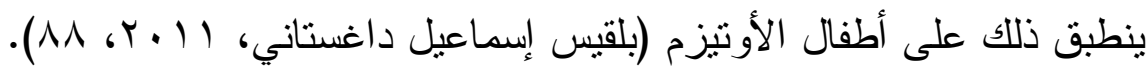
و المسميات السابقة كلها تهدف إلى وصف فئة معينة تحمل الصفات نفسها

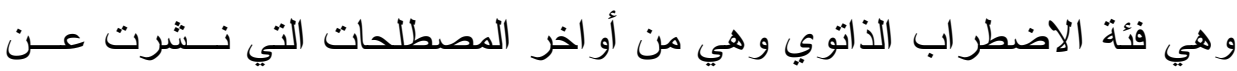


الطفل الذاتوي، وترى الباحثة أنه لم يتفـق البــاحثون علــى تعريــف محــد لاضطراب التوحد أو الأتوية كما هو الحال لبقية الفئات الخاصة وذلك للأسباب التالية:

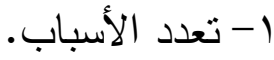

ץ- أن اضطر اب التوحد ليس درجة واحدة وإنما هو درجات منها البسيطة،

$$
\text { و المتوسطة، و الثديدة. }
$$

r- أن أعر اضه كثيرة جداً وليس بالضرورة أن تكون هذه الأعر اض موجودة

$$
\text { جميعها لدى أي طفل مصاب بالتوحد. }
$$

ع- تعدد الثرائح التي اهتمت بحالات التوحد كالطبيب، و الأخصائي النفسي، و أخصائي التربية الخاصة، و أخصائي التخاطب، ولنئ وعالم الاجتماع.

0- تعدد المصطلحات التي استخدمت لتدل على أعر اض التوحد لما يتخلله من غموض وتعقيد، ورنالك من يعده مرضاً، وآخر يعده اضطر اباً في السلوك، و آخر يعده إعاقة عقلية.

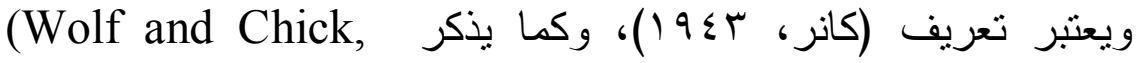
(1980 أول أسلوب استخدم لنتخيص الذاتوية ويوضح كانر النقاط التالية في تعريف التوحد مركزاً على الصفتين الأولى والثانية، حيث حدد كانر أن هاتين الصفتين هما معيار لنتخيص حالات التوحد: 1- النقص الثديد في التو اصل العاطفي مع الأخرين. ץ- حب الروتين "الكره الثديد لأي تغيير في بر امج حياته اليومية". r- التمسك الثديد غير المناسب بالأثياء. 
ع- الظهور على هيئة طفل أصم أبكم.

ه- الاظهار أو الاحتفاظ ببعض القدر ات المعرفية الجيدة.

(نايف بن عابد الذراع، 0 . . ب، 7 ( )

و عرف (Osterling, 1994) الاضطر اب الذاتوي على أنه "الاضطر اب

الذي يتضمن قصور اً في التو اصل الانفعالي وتأخر في النمو اللفظي المصاحب بشذوذ في الثكل ومضمون الكلام و الترديد الآلي، وعدم القدرة على استخدام الضمائر بالإضافة إلى النمطية و الاصر ار على الطقوس دون توقف مع وجود

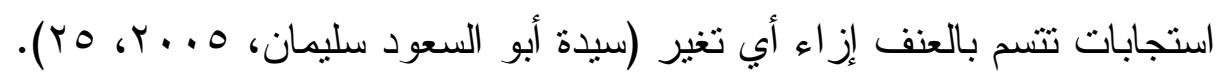

ويكز (خليل، ب99 (1) أن الاضطر اب الذاتوي لله مجموعة من محددات

$$
\text { الثخصية ومنها: }
$$

ا- اضطراب و اضح في الارتقاء الاجتماعي اللغوي مصحوب بأنماط سلوكية نمطية.

r-زملة سلوكية تتتج عن أسباب متعددة غالباً ما نكون مصحوبة بنسبة ذكاء منخفض.

ب- التأكيد على حقيقة الذاتوية تتسم باضطر اب في التفاعل الاجتماعي

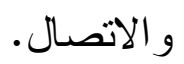

ع- نسبة حدوث هذا الاضطر اب ما بين ب - ع لكل عشرة ألاف طفل.

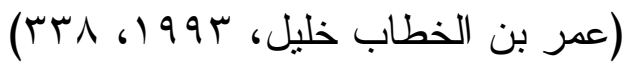

ومن أكثر التعريفات المقبولة التي اقترحت لتعريف التوحد تعريف

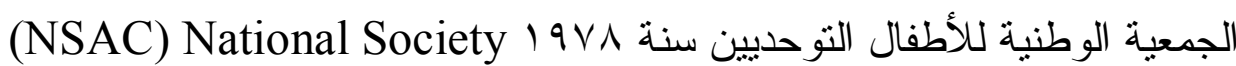


for Autistic Children

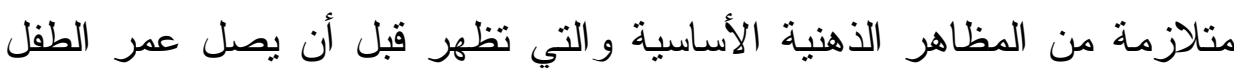

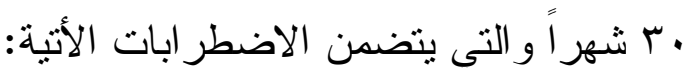
اضطر اب في سرعة أو تتابع النمو. اضطر اب في الاستجابات الحسية للمثير ات. اضطر اب في الكلام و اللغة و السعة المعرفية.

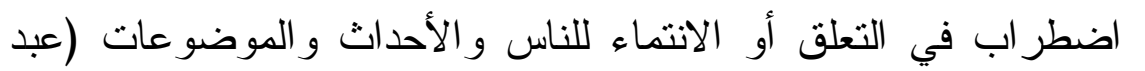

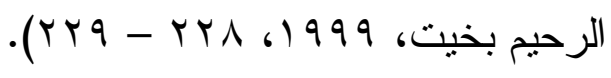

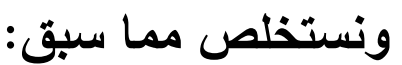

أن اضطر اب التوحد ما هو إلا نوع من الاضطر ابات الارثقائية المعقدة

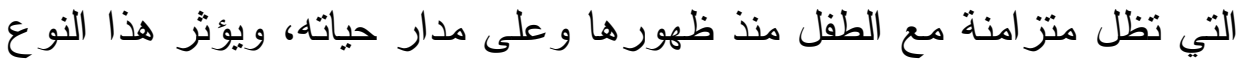
من الاضطر ابات الارتقائية على التواصل Communication سواء أكان

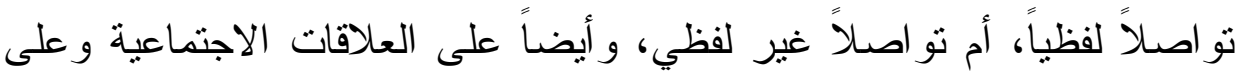
أغلب القدرات العقلية لهؤلاء الأطفال المصابين بالتوحد، ويظهر في خلال السنوات الثلاثة الأولى من عمر الطفل ويفقده الاتصال و الاستفادة ممن حوله لأله

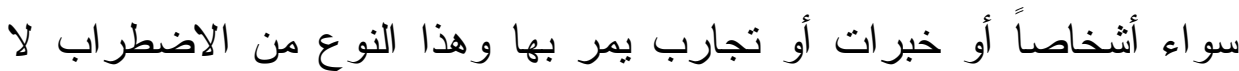
شفاء منه ولكنه ممكن أن يتحسن بالتنخل العلاجي و التندريبي المبكر . r) نسبة انتثار اضطراب التوحد:

Center أثنار مركز مقاومة الأمر اض و الوقاية منها بالو لايات المتحدة for Disease Control and Prevention ترتبط بأي تاريخ أسرى مرضى أو أي ممارسات أسرية أو ثقافية، وقد أصسـدر

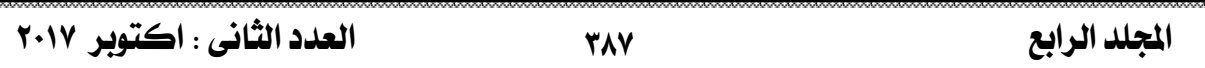


المركز احصائيات نتشير إلى أن هنالك حو الي خمسمائة ألف شـــص بالو لايــات

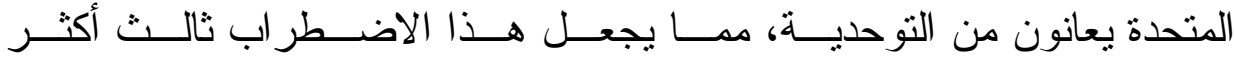

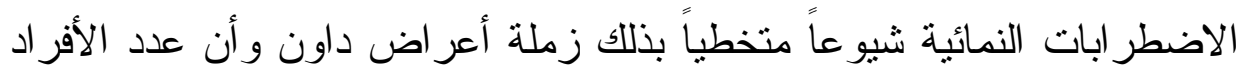

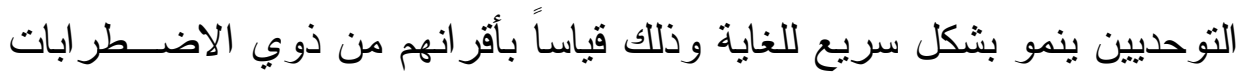

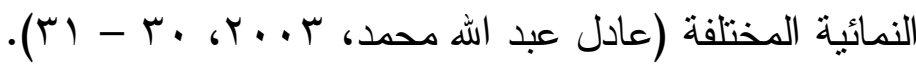

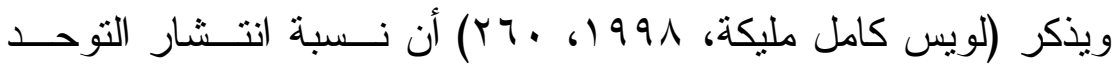

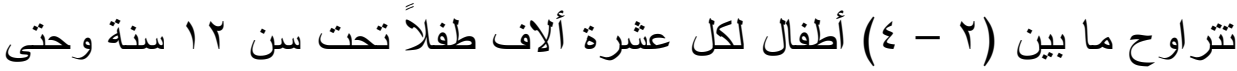

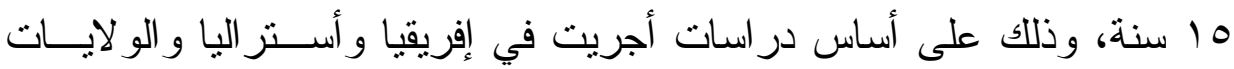

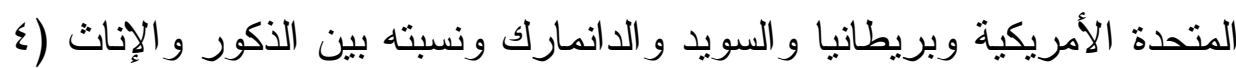

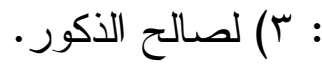

وفقاً للإحصاءات التي نــثدها الاتحــاد القـومي لدراســات وبحــوث

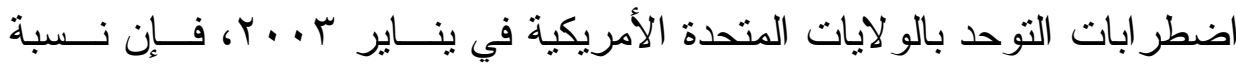

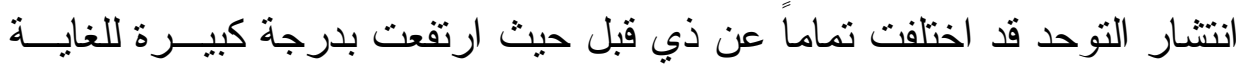

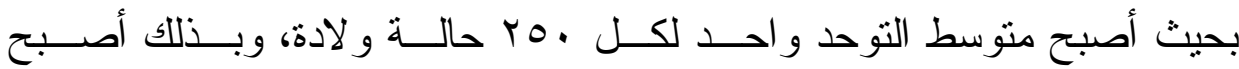

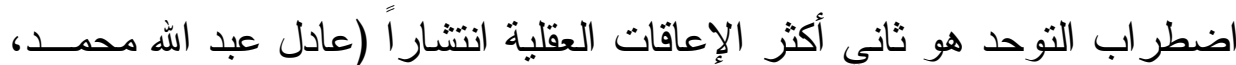
. (r... . . . .

وفي مصر أثنار المؤتمر العربي السادس للطب النفسي عام ؟99 199

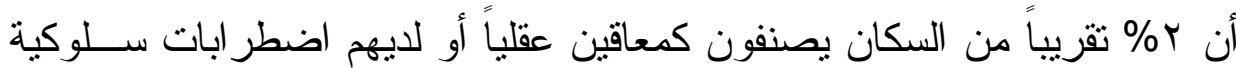
أو انفعالية يكونون مصابين بالتوحد أو الحالة الثبيهة بالتوحســ Autitisticike

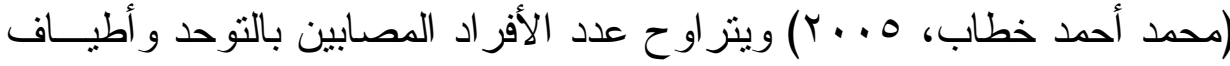

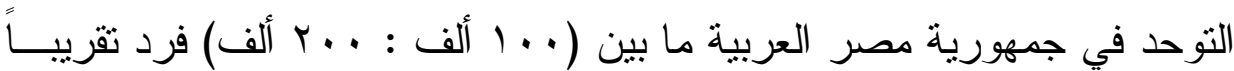
(عثمان لبيب فر اج، 1997 1)، (1)). 
ويتضح مما سبق أن نسبة انتشار اضطر اب التوحد تختلف من بلد إلـى لـى

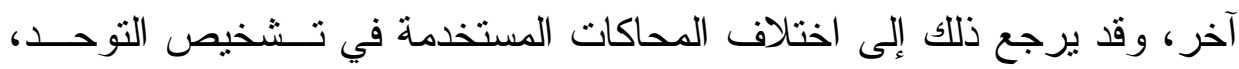

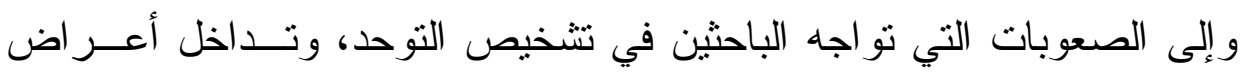

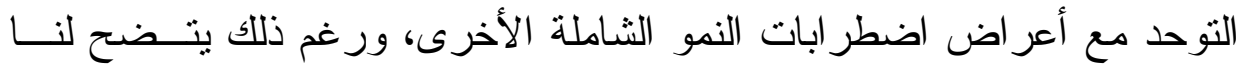

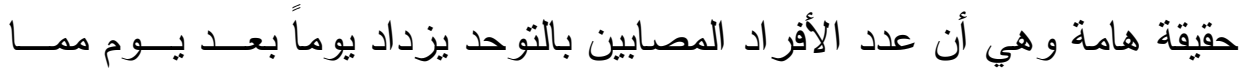
يجعلنا نحتاج إلى مزيد من الدراسات التي تهدف إلى زيادة فهم هذا الاضطر اب،

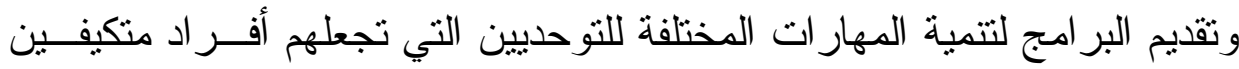
اجتماعياً.

ويزداد انتشار التوحد عالمياً دون معرفة الأسباب المؤدية إلى ذلك بشكل

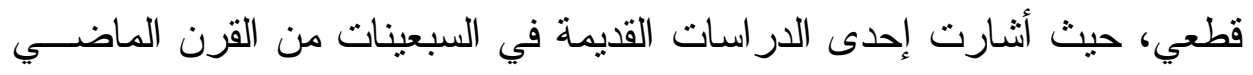

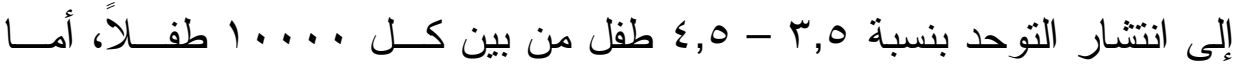

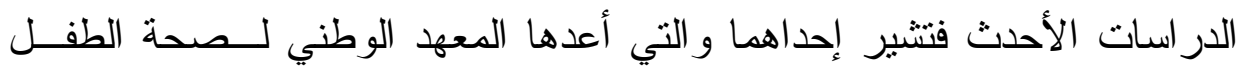

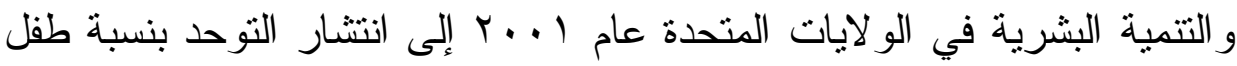

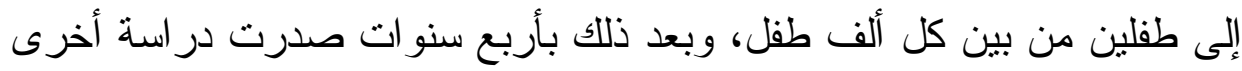

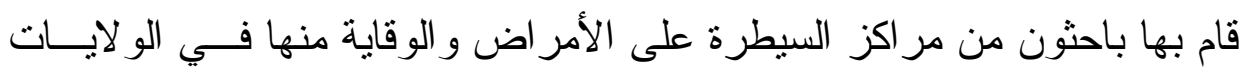

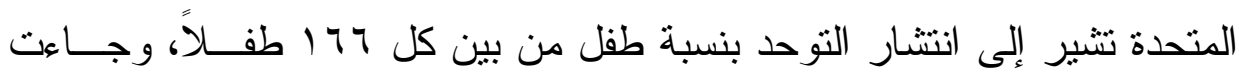

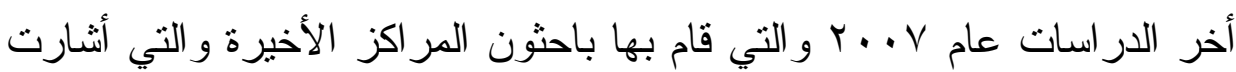

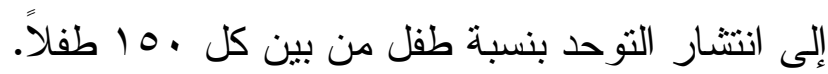

ويعتقد أن سبب ارتفاع معدلات الإصابة بالتوحد يعود إلى تقدم أسـاليب

$$
\text { الكثف عن هذا الاضطر اب (توبخ، r... (Y). }
$$


لم يصل العلماء و الباحثون بعد إلى سبب أكيد يمكن الاستتاد إليه حتى

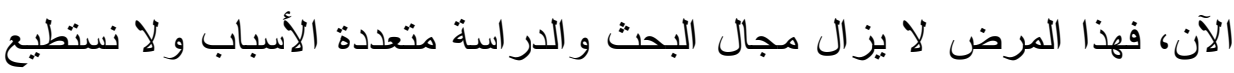

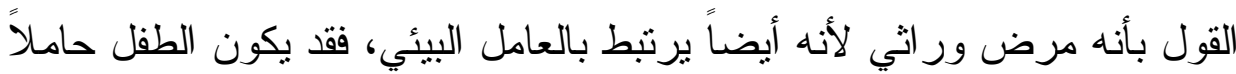

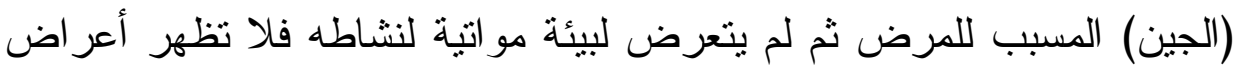

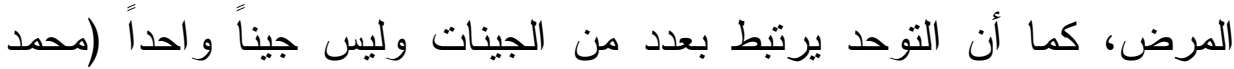

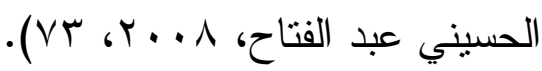

وفيما يلي عرض للأسباب التي تؤدي إلى الإصابة باضطر اب التوحد:

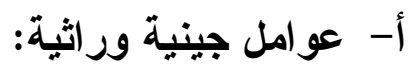

حيث يكون للطفل من خلال جيناته قابلية للإصابة بالتوحد، ولقد أثـــارت الأبحاث الخاصة بالجينات بوجود ارتباط بين الإصابة باضطر اب التوحد و أحـــ

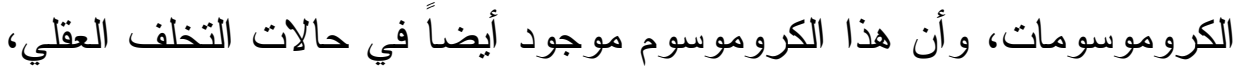
وأن هذا الكروموسوم يسبب مشاكل في اللغة و النمو الحركي كما تــزداد نـسـبة فئة

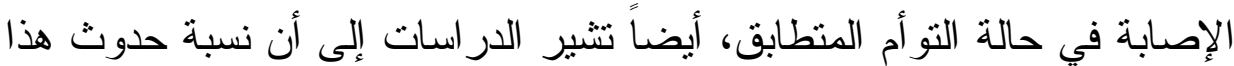

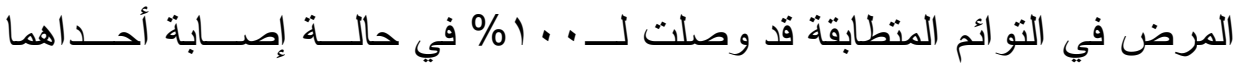
(Adel Abdullah Moored Ali, 2014,6).

كما أن هنالك من يعزى الإصابة باضطر اب التوحد إلى خلل فـي بعـض

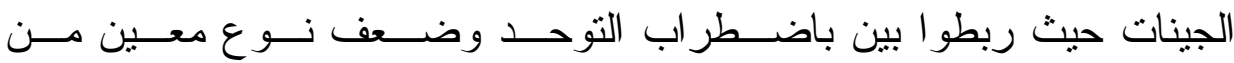

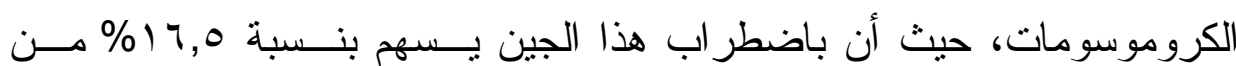

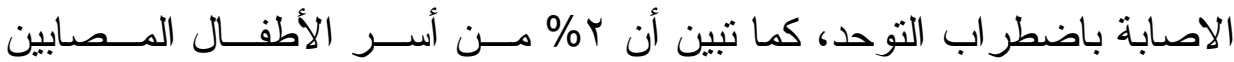

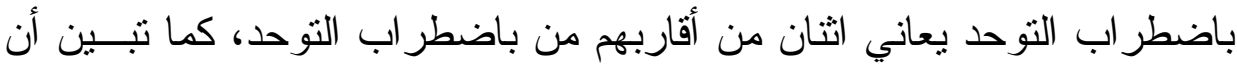


ارتفاع نسبة انتثـار باضطر اب التوحد بين التوائم المتماتلة عن النو ائم الأخويـــة

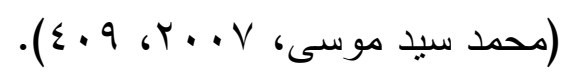

يتفق معه الظاهر في أنه بالفعل للذاتوية سبب جيني من خــالد المقارنـــة

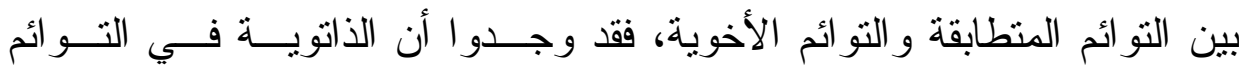

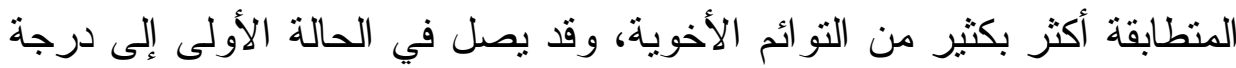

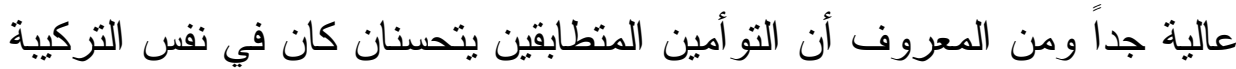

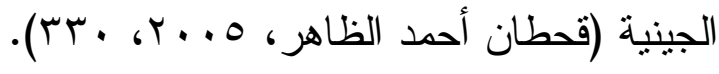

وكما تنتقل الجينات الكثير من الخصائص البشرية من الو الدين إلى طفلهم كالون و الطول و الثكل وغير ها، بالإضافة إلى الكثير من الاضطر ابات الحيوية .Inborn error of Metabolism

وقد توصل العلم الحديث إلى معرفة البعض منها ومعرفة مكانهــا علـى

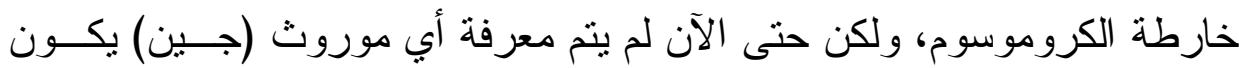

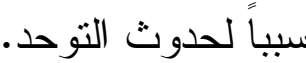

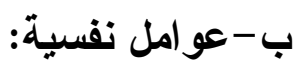

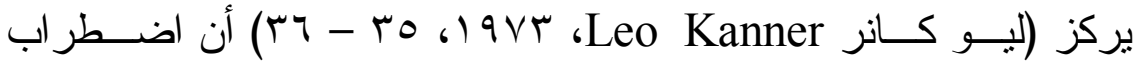

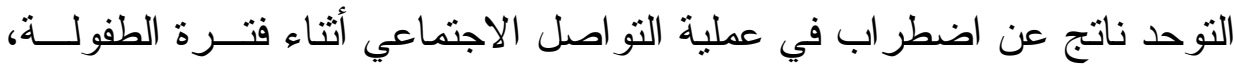

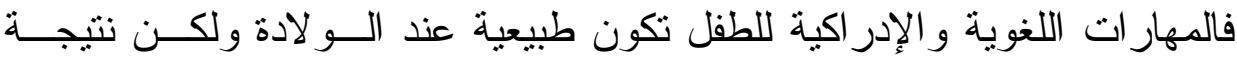
لظروف التتشئة الاجتماعية السيئة ينسحب الطفل من البيئة المحيطة به، ويحدث

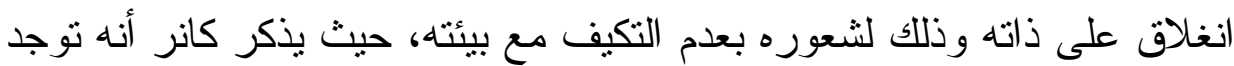

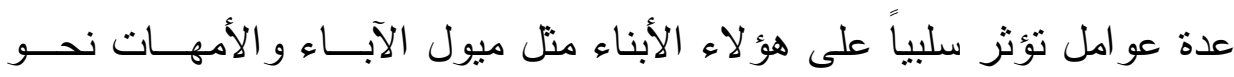

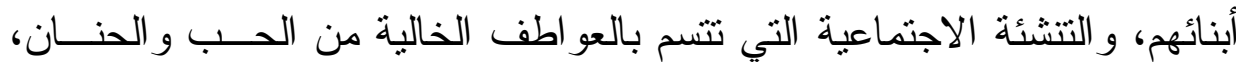

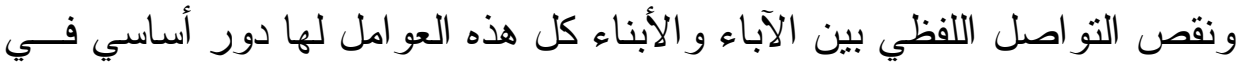


إعاقة التو اصل لدى هؤ لاء الأبناء وتسبب انسحابهم مــن العــالم المحـيط بهـــ

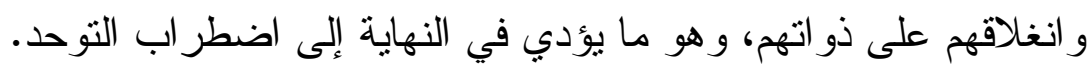

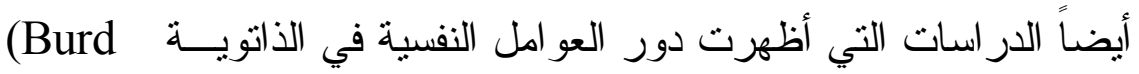

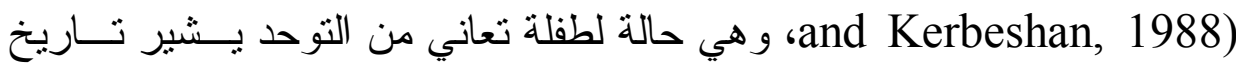

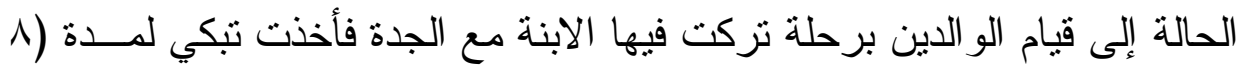

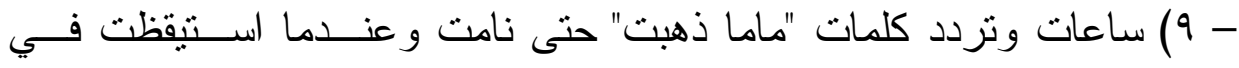

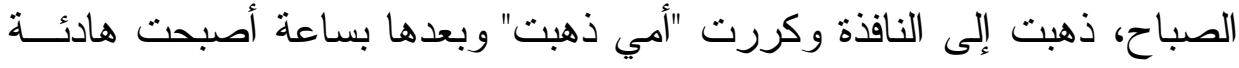

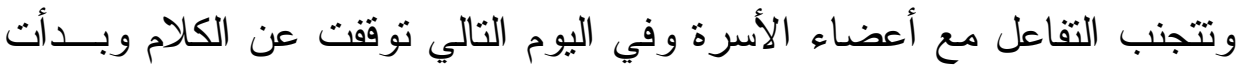
أعر اض التوحد الأخرى كالحملقة واللعب بشكل غير اعبر مميز (الهامي عبد العزيز،

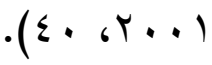

وبالنظر إلى ما أنثارت إليه الدراسات الحديثة من سوء معاملة الوالــدين

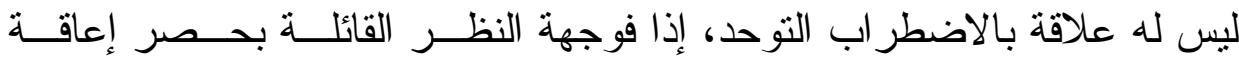

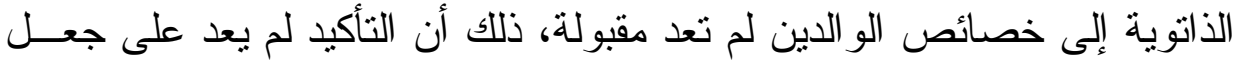

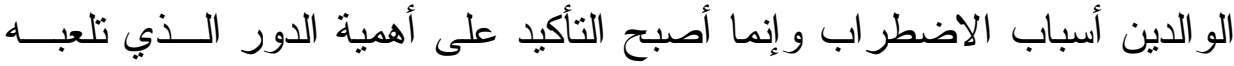
الجو انب المعرفية و الاضطر ابات النمائية لدى الأطفال التوحديين أنفسهر.

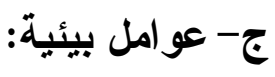
أن هناك عدداً من البحوث أثثتت علاقة الإصابة بالتوحد كنتيجة التلــوث

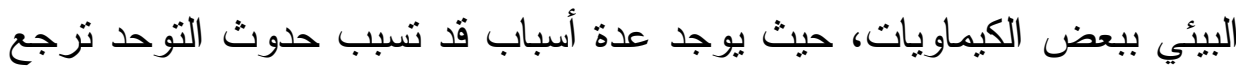

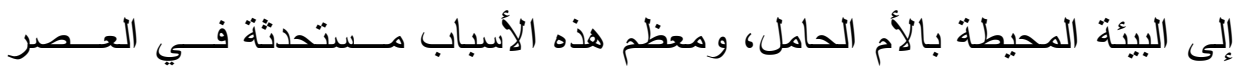

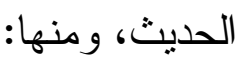

1- تلوث البيئة خاصة في التجمعات السكانية في مناطق تكثر فيهــا مخلفــات كيميائية أو مصافي البنرول أو حدائق كبرى. 
r-سوء التغذية ونقص بعض العناصر الأساسية من الطعـام بـسبب بعـض

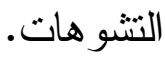
r- إفر اط الحامل في التخخين أو تناول المخدرات و الكحــول سـبب لظهــور

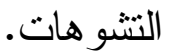

ع- حمل الأم بعد سن الخامسة و الثلاثثين يزيد احتمال و لادة طفل غير طبيعسي

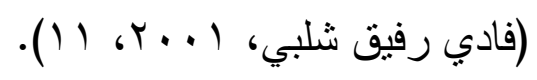

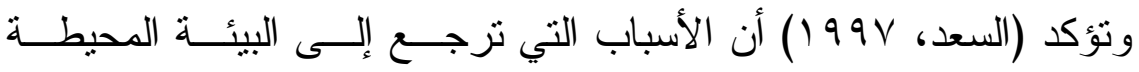

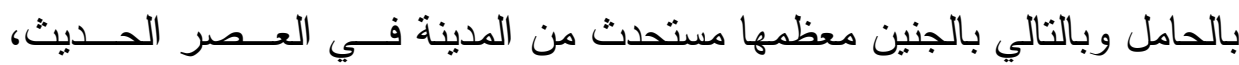
ومنها الاشعاعات بأنو اعها وكذلك التجمعات السكانية الموجودة في مناطق تكثـر

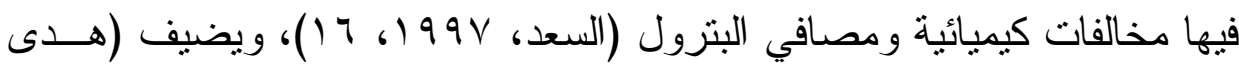

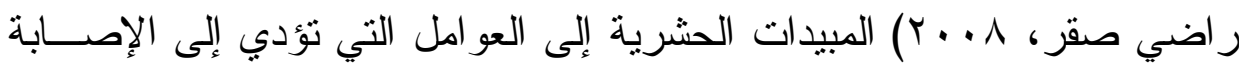

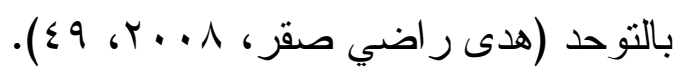

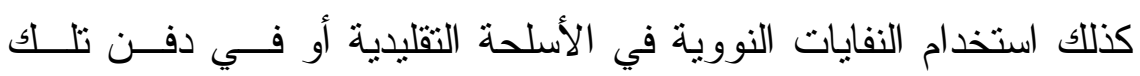
النفايات بشكل يجعل من المكن بالنسبة لها أن تؤثر على الأفراد (عادل عبد الله

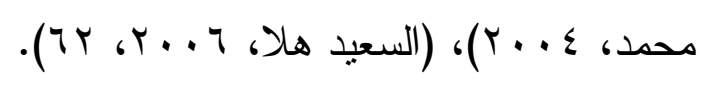

يمكن تصنيف معظم النظريات التي تتاولت مسبيات اضــطر اب النوحسـ

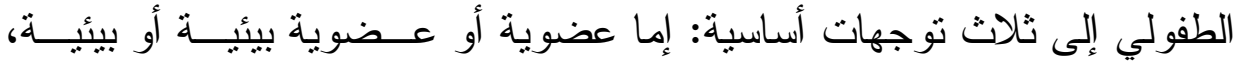

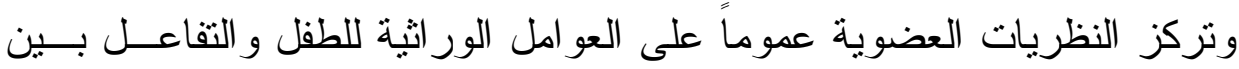

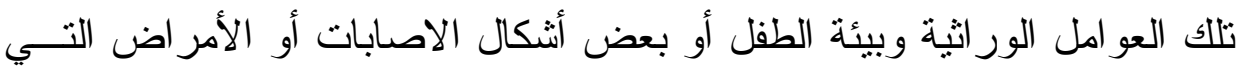

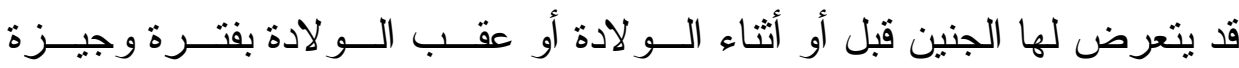

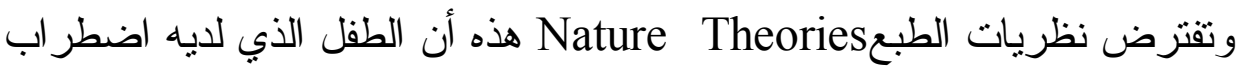

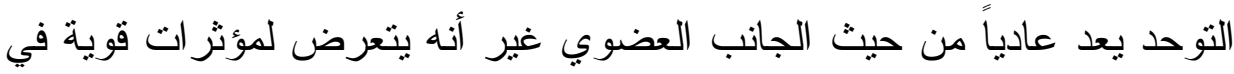


مرحلة مبكرة جداً من حياته تشفر عن إصابته بالاضـــر اب النفـسي الــثديد

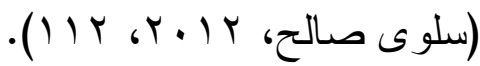

$$
\begin{aligned}
& \text { د - عو امل بيولوجية: }
\end{aligned}
$$

در اسة (Joub Deborah, 2003) لا تستبعد الأسباب البيولوجية، وفـي

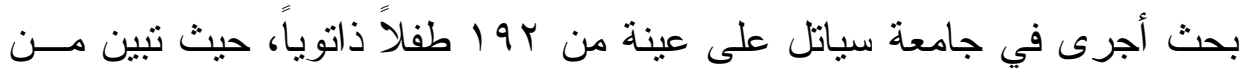

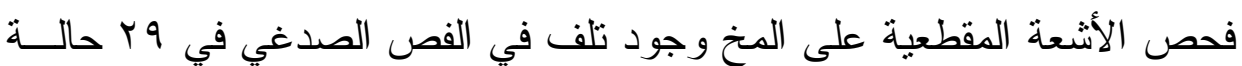

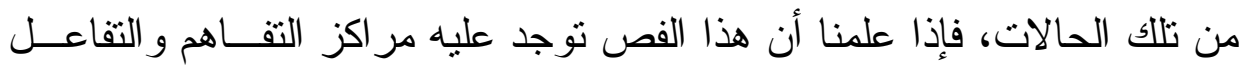

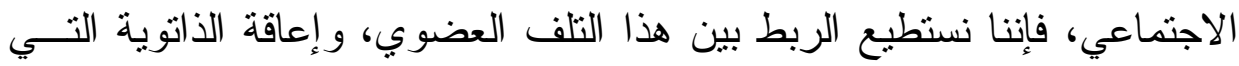

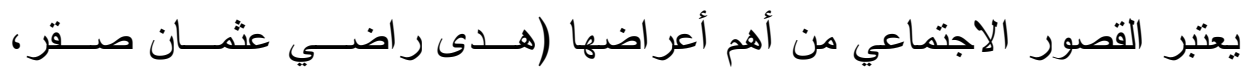
. (0. r. r.

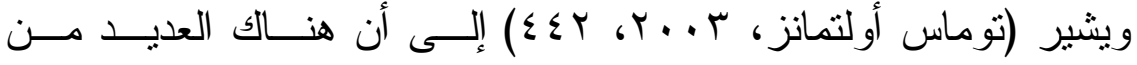
الاعتبار ات التي تجعل التفسير ات البيولوجية لاضطر اب التوحد مقبولـــة، ومسـن التـن أهمها: - (الاعتا:

$$
\text { 1- أن عمر بداية الاضطر اب التوحدي مبكر جداً. }
$$

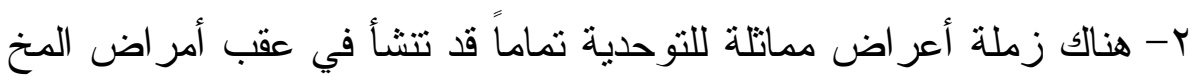

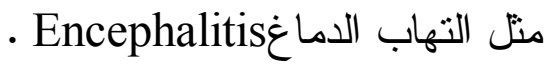

r- أن الضعف العقلي يرتبط في الغالب بنوع من اضطر اب وظيفـــة المـــخ،

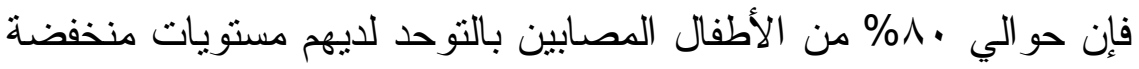

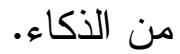
ع- وجود أنماط شاذة من موصلات المخ لدى الأطفال المصابين بالتوحد من خلال رسام المخ الكهربائي (EEG). 


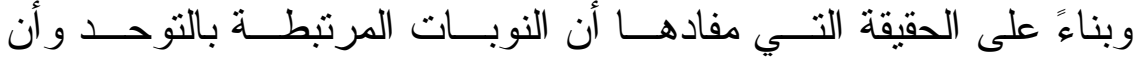
الاحتمالات غير الطبيعية المثارة قد لوحظت لدى التوحديين استجابة للمهام التي

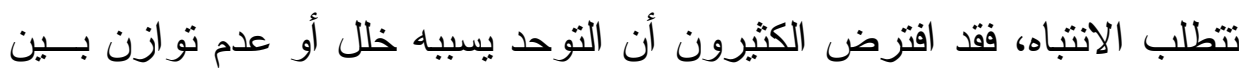
الإثارة و الكتب في النظم العصبية الرئيسية بما في ذلك القترة المخية (فهد بــن

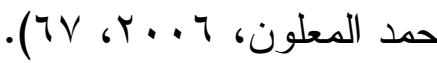

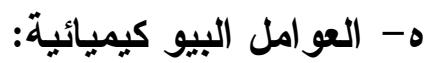

Key احتمالية وجود انخفاض في مستويات أنزيمات بيتــداز الرئيــسية

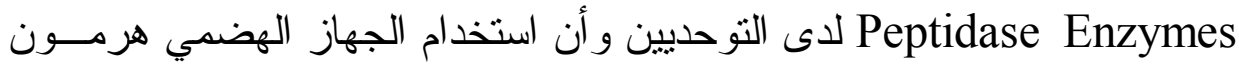

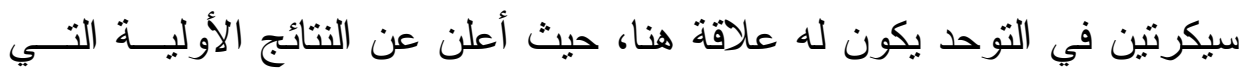

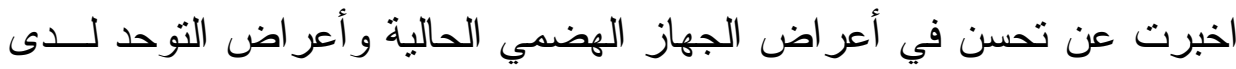

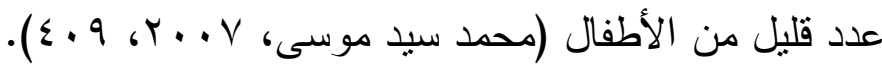

كما أنثارت الدر اسات إلى أنه توحد علاقة بين العو امل الكيميائية العصبية Neuro Chemical

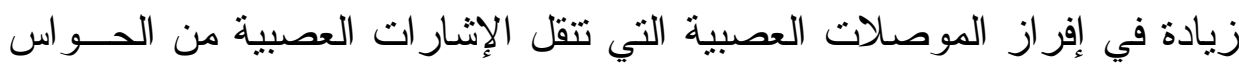

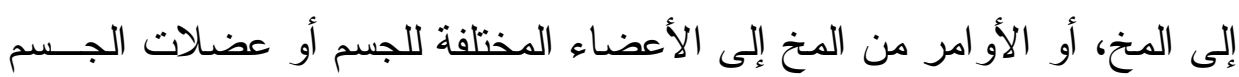

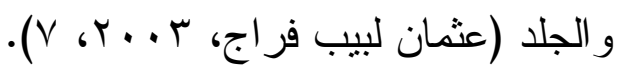

و هذا الاكتثاف ليس خاصاً باضطر اب الذاتوية فقط، فالأطفال المتخلفــون

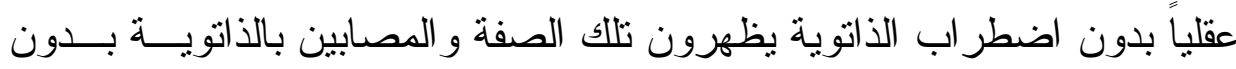

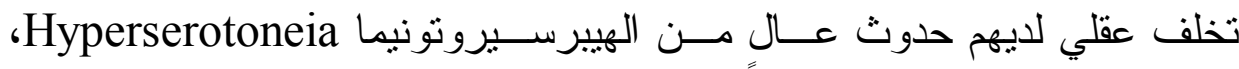

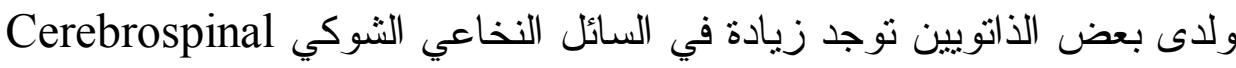

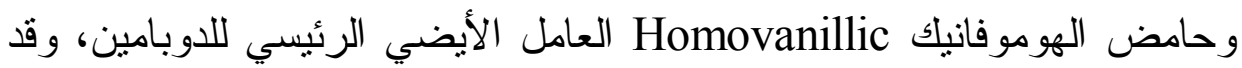

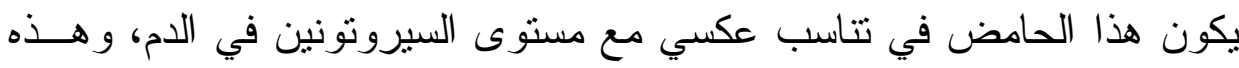




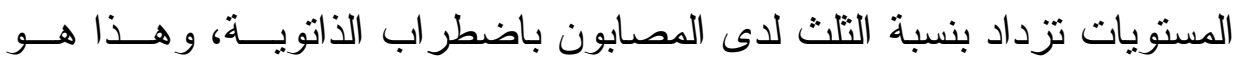

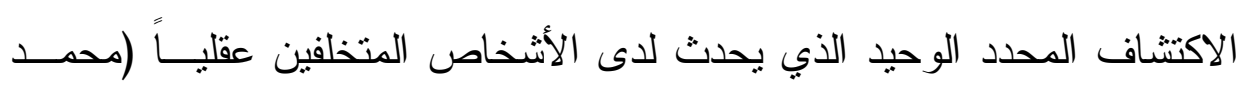

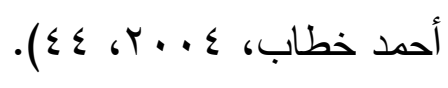

أسباب صعوبة تحديد العوامل المؤدية للإصابة بالتوحد:

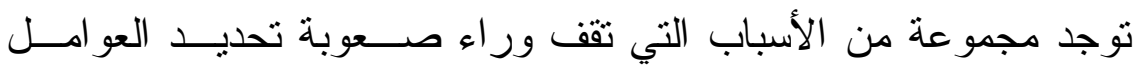

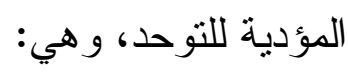

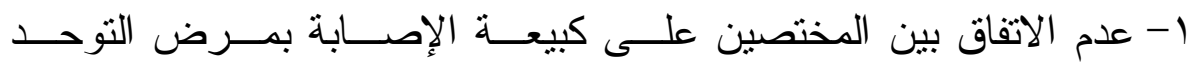
و اضطر ابات التطور العامة. r- النتخيص يعتمد على الأخصائيين وتجاربهر.

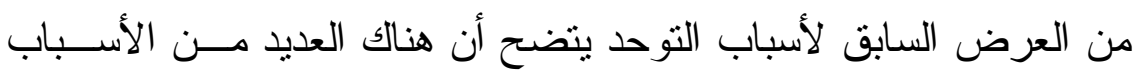

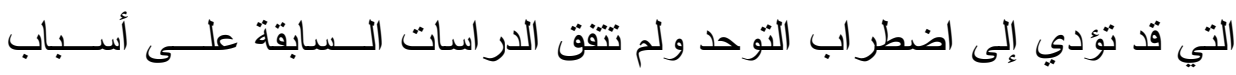
محددة بمكن تحديدها على أنها سبب إصابة الأطفال بمرض التوحد، بينما تعـد التهاب

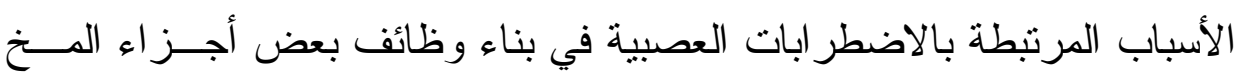

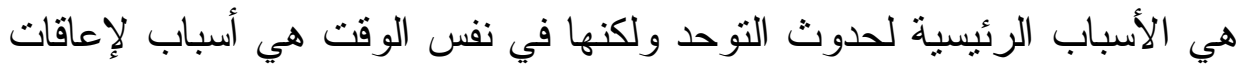

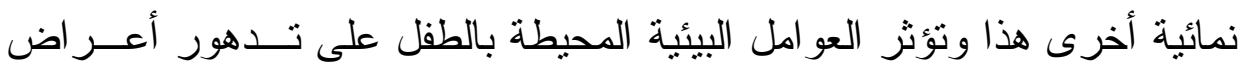
التوحد لديه أو تتمية مهار اته وقدر اته المختلفة. كما تعد الأسباب البيولوجية التي قد تكون سبباً لحدوث اضطر اب التوحد،

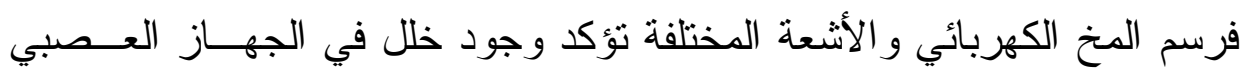

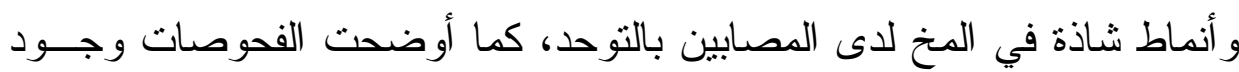

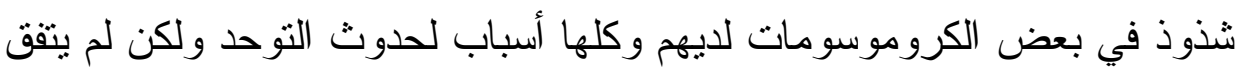


العلماء حتى الآن على سبب رئيسي ومحدد لحدوث إعاقة التوحد يختلــف عـن

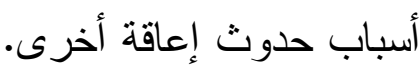

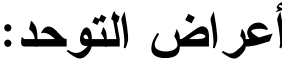

أن الثنكل الأساسي للطفل ذي اضطر اب النوحد يشمل الفثل التام أو شبه

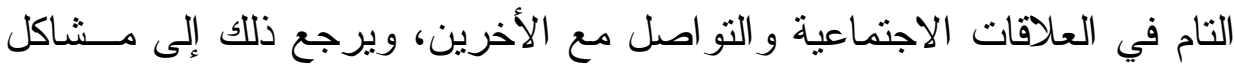

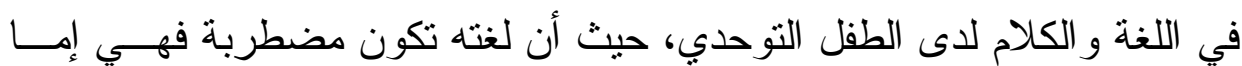

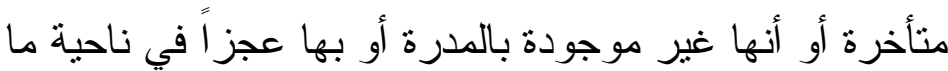

لقـــ أثــــارت (Wendy Brown, 1990) أن الأغـــر اض المـصـاحبة

لاضطر اب الذاتوية تشتمل على جو انب أساسية منها الجانب الاجتماعي ويتمثـلـل في اختلال القدرة على التفاعل الاجتماعي وعدم القدرة على التو اصل واستخدام

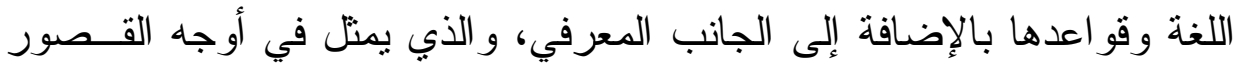

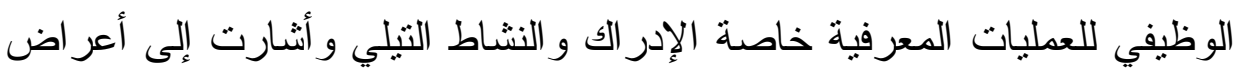

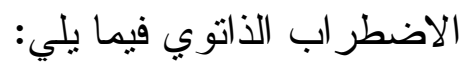

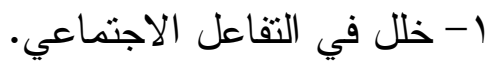

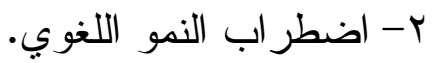

ץ- اضطر اب التو اصــ Communication Disorder علـــى المـستوى الاجتماعي و المعرفي وقصور في القدرة على التخيل. ع- اضطر اب التأزر الحركي Motor Cooedination. 0- نمطية السلوك الروتيني. ومن الأعر اض المميزة للتوحديين، عدم القدرة على الاستجابة للأخــرين،

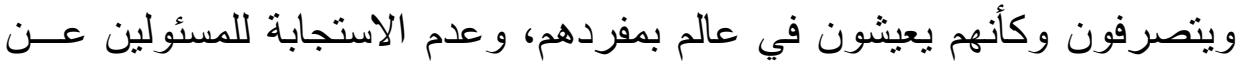


رعايتهم بصورة مناسبة فهم لا يميلون إلى معانقــة الأم أو الفــرح لوجودهـــا،

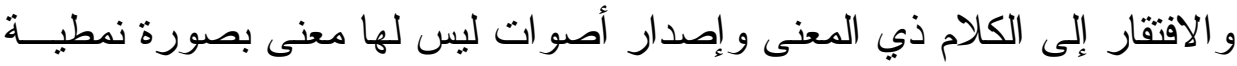

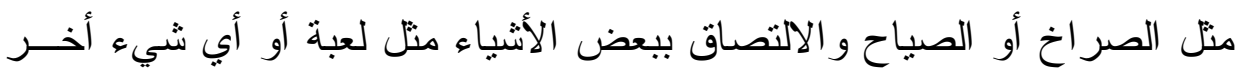
ومن هذه الأعر اض:

1- أن يجد الطفل صعوبة في تكوين العلاقات الاجتماعية وعدم قدرته علـى التو اصل اللفظي و المشاركة في الأنشطة مع أقر انه.

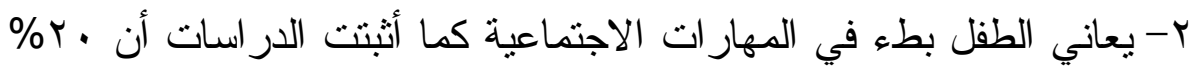

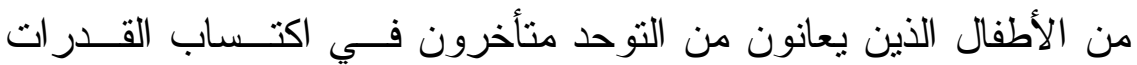
العقلية و اكتشفت أن لدى بعض المصابين بالتوحد مهار ات ومو اهب معينة في مجالات مختلفة متل الموسيقى و الحساب و الرسم. ץ- يعاني الطفل التوحدي من حركات متكررة مثل الدوران، هز الـــرأس، أو

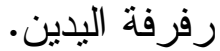

ع - يعاني هؤ لاء الأطفال من الروتين في النظام اليومي و الألعاب وهكذا. ه- يعاني أيضاً من بطء في تصور اللغة. 1- لا يستطيع أن يعرف مشاعر الأخرين.

V- غير معتاد للأحاسيس الجسدية مثل أن يكون حساس أكثر من المعتـاد أو

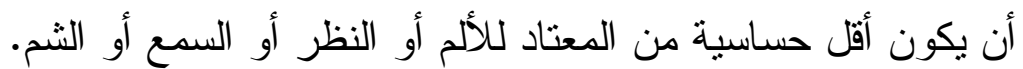
^- قد يكون نشطاً أكثر من المعتاد أو أن تكون حركته أقل من المعتاد. 9- لايه اضطر اب في الأكل و الثرب و النوم متل قصر الطعام علـى نــوع

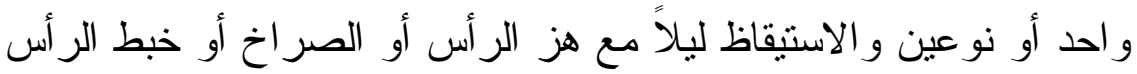
في الحائط. 
تختلف هذه الأعر اض من شخص لأخر ويمكن استخلاص أهم أعـراض

$$
\begin{aligned}
& \text { التوحد فيما يلي: } \\
& \text { 1- يكرر كلام الأخرين. } \\
& \text { r- لا يهتم بمن حوله. } \\
& \text { r- لا يحب أن يلمه أحد. } \\
& \text { ع- يقاوم التغيير في الروتين. } \\
& \text { 0- لا ينظر في عين من يكلمه. } \\
& \text { 7- نوبات غضب شديدة دون سبب. } \\
& \text { - V - لا يلعب مع الأطفال. } \\
& \text { 1- لا يخاف من الخطر. } \\
& \text { 9- يقاوم الطرق النقليدية في التعليم. } \\
& \text {. } 1 \text { - يتصرف وكأنه لا يسمع. }
\end{aligned}
$$

1 - لايه إما نشاط ز ائد ملحوظ أو خمول مبالغ فيه.

$$
\begin{aligned}
& \text { r ا - ضحك هستيري في أوقات غير مناسبة. } \\
& \text { rا - يستمتع بلف الأثياء أو الدور ان حولها. } \\
& \text { ع ا- تعلق غير طبيعي بالأثياء. } \\
& \text { تثخيص التوحد: }
\end{aligned}
$$

لعل هذا الأمر يعد من أصعب الأمور و أكثرها تعقيداً وخاصة في الــدول

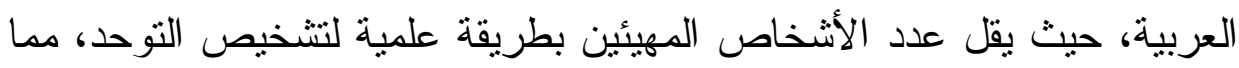


يؤدي إلى وجود خطأ في التشخيص أو إلى تجاهل التوحد في المر احل المبكــرة

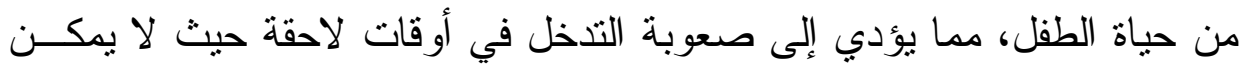

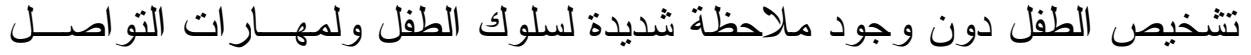

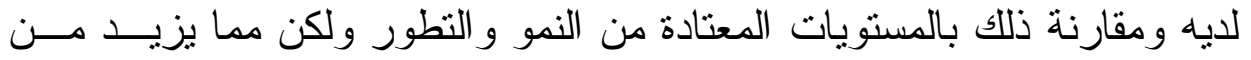

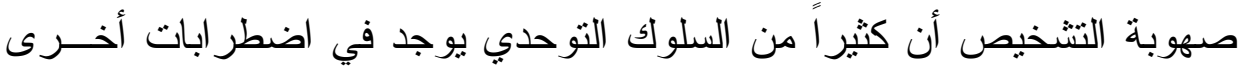

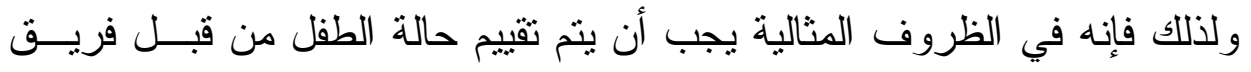
كامل من تخصصات مختلفة حيث يمكن أن يضم هذا الفريق:

$$
\begin{aligned}
& \text { 1- طبيب أعصاب. } \\
& \text { r- طبيب نفسي. } \\
& \text { r- طبيب أطفال متخصص في النمو. } \\
& \text { ع - أخصائي نفسي. } \\
& \text { 0- أخصائي علاج لغة و أمر اض نطق. } \\
& \text { 1- أخصائي علاج مهني. } \\
& \text { V أخصائي تعليمي. }
\end{aligned}
$$

يعتمد التشخيص الاقيق على الملاحظة المباثرة لسلوك الفرد وعلاقاتـهـ

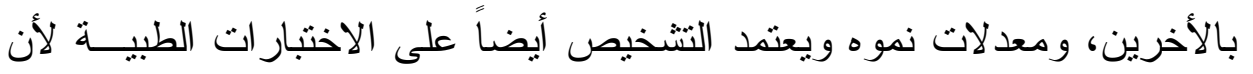

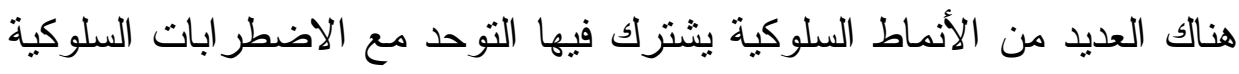

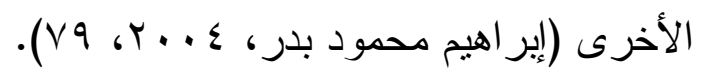

وقد وضعت الجمعية الأمريكيــة للطــب النفـسي الــليل الاحــــئي

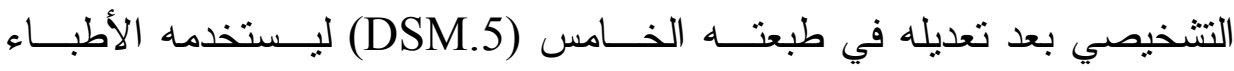


و المتخصصين بالإعاقات الفكرية و العقلية و السلوكية لتقسيم الحالات المرضــية التي يتعاملون معها للخروج بالتشخيص المناسب.

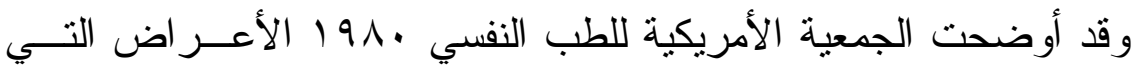

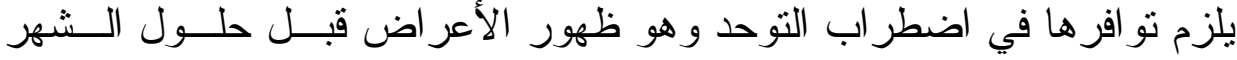

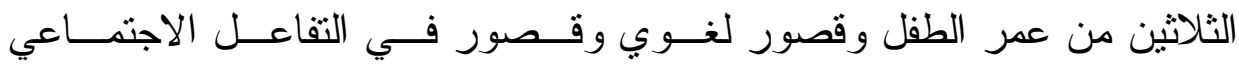

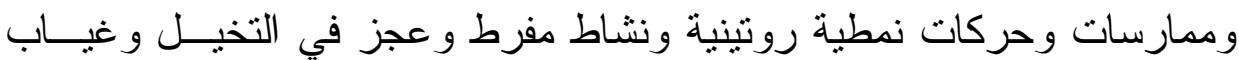

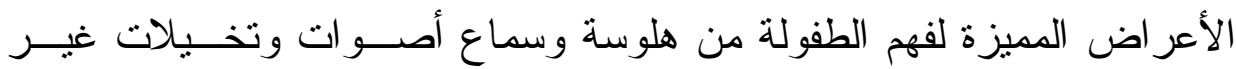

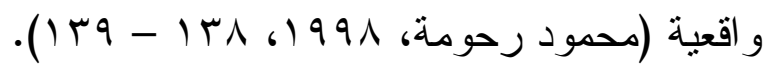

ويبدأ التشخيص المبكر بملاحظة الطفل من سن 1 ا شــهر حتـى ســنة

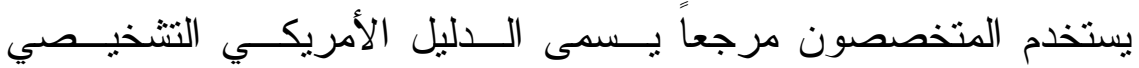

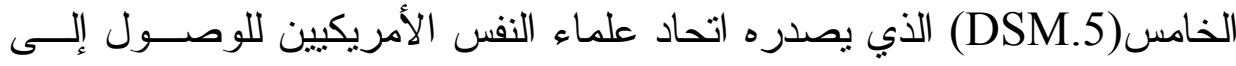

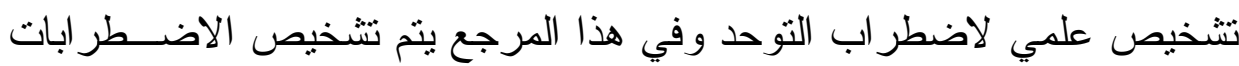
المتعلقة بالتوحد تحت العناوين التالية:

$$
\text { اضطر ابات النوحد. النمو الدائمة. }
$$

متلازمة أسبرجر Asperger's Syndrome.

متلازمة ريت Ret's Syndrome.

اضطر اب الطفولة التراجعي. 
ويتم استخدام هذه المصطلحات بشكل مختلف أحياناً من قبل المتخصصين

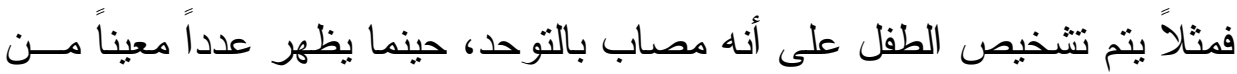

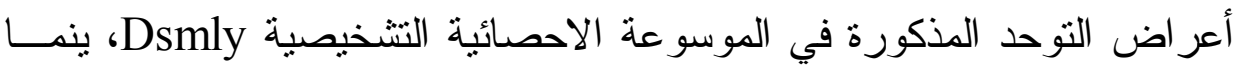

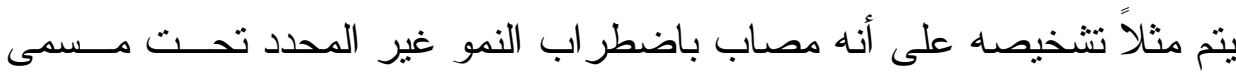

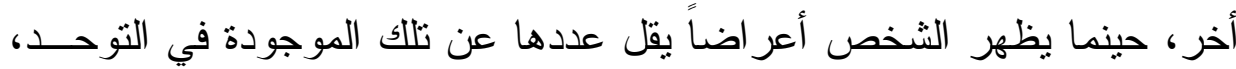

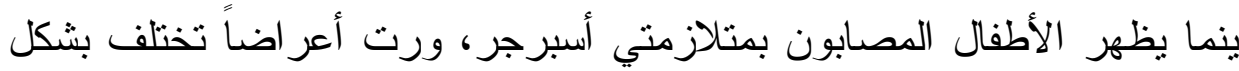

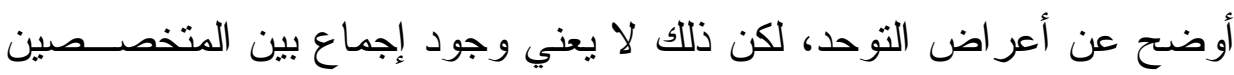

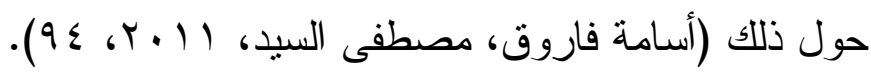
النظريات المفسرة للتوحد:

لقد اهتم الكثير من العلماء، وظهرت تفسير ات عديدة في محاو لات مــنهم إلى فهم هذا الاضطر اب وفيما يلي عرض لهذه النظريات:

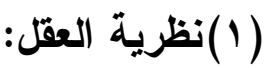

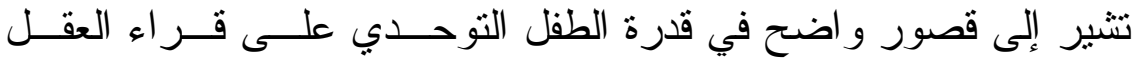
فالأطفال العاديون في عمر الر ابعة لايهم القدرة على فهم ما لدى الأخرين مسن

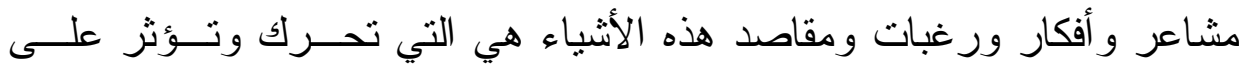

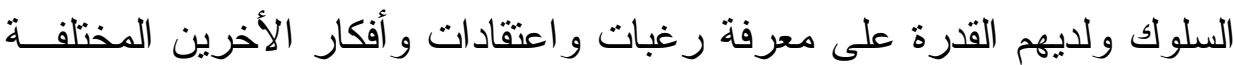

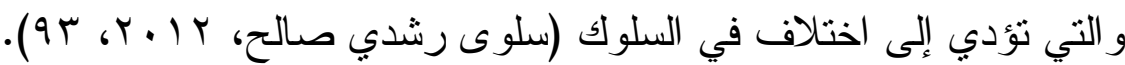
الأطفال التوحديون بمقدور هم تكوين اعتقادات معينة أو إدر الك ما يعتقـــهـ الأخرون إلى جانب ذلك فهم لا يستطيعون التعبير عن الانفعالات المختلفة، أمسـا

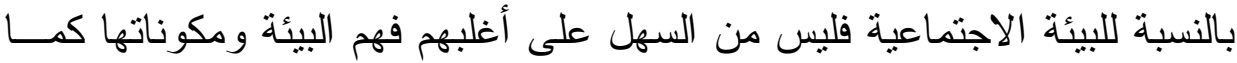
أن سلوكياتهم في أغلبها غير مقبولة.

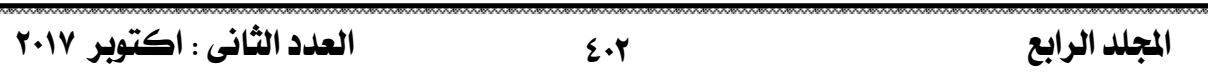


تشير إلى أن الطفل التوحدي يعد عادياً من حيث الجانب العضوي غيــر

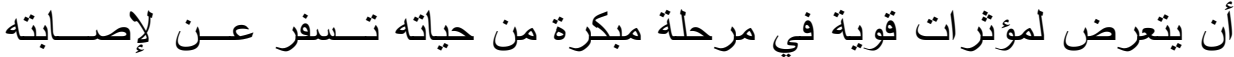

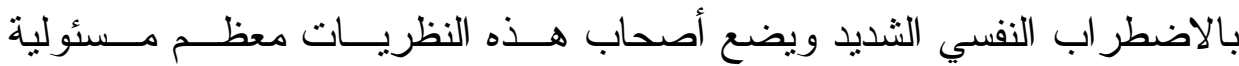

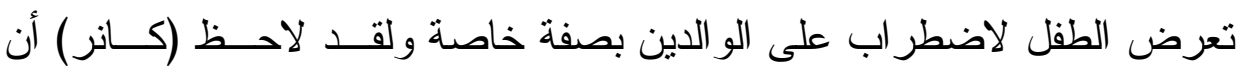

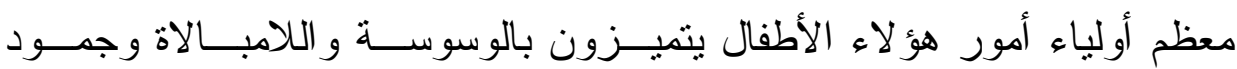
المشاعر العاطفية.

ونظراً لأن تلاك الأوصاف المبكرة لأولياء أمسـور الأطفــال التوحسـيين تضدنت اتسامهم باللامبالاة وتبلد المشاعر و العزلة و التقليدية أو الرسمية، لـــلك الكاءل

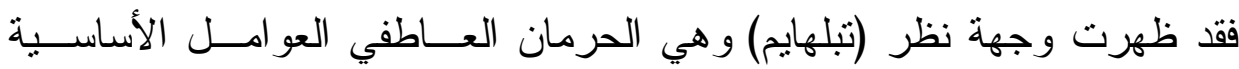

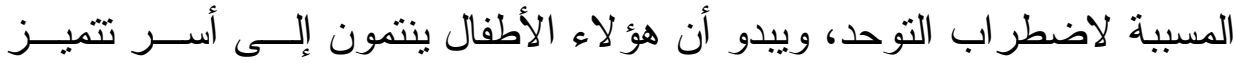

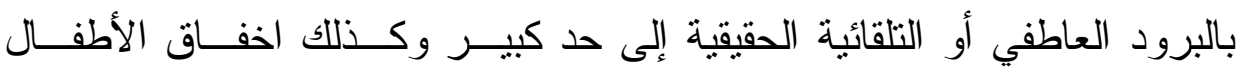

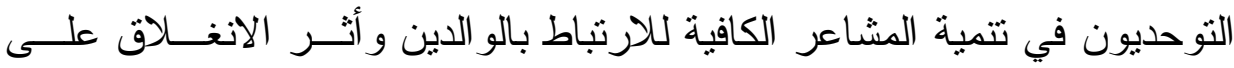

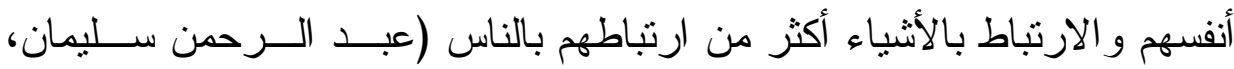
. ( $\{$ r. T. T)

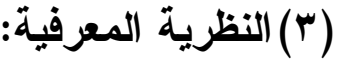

لا أحد يذكر أن الأطفال التوحديون لايهم مشكلات معرفية شــديدة تــؤثر

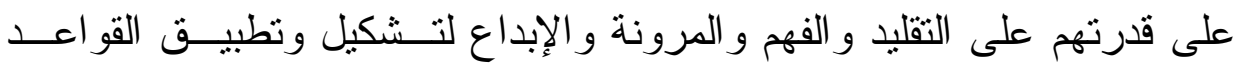

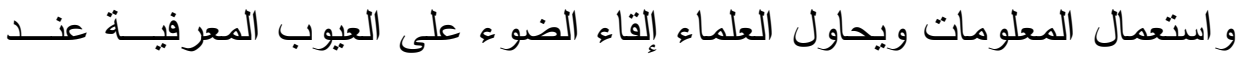
الأطفال التوحديين.

وقد امتدت وجهة النظر هذه حول الخلل المعرفي لدى الأطفال التوحديين

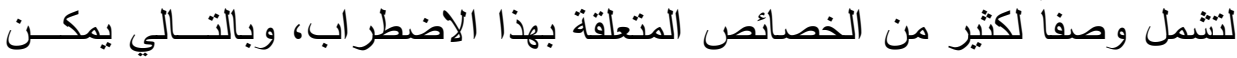


تفسير خصائص مثل المصـاداة وعدم الكــلام وعكـس الــضمائر ومحدوديــة المفردات في ضوء عدم قدرة الأطفال التوحديين على تكوين مفهوم "أنا - و أنت" ومن ثم لا يسنطيع الكلام بصورة صحيحة وبالمنل فإن اصر ار الطفل على إيقاء البيئة ثابتة دون حدوث أي تغيير و التكر ار الآلي (عبد المعبود منصور محمـد، .

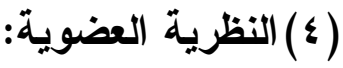

ترى أن هؤلاء الأطفال يأنون إلى العالم بعجز فطري ذا أساس بيولــوجي

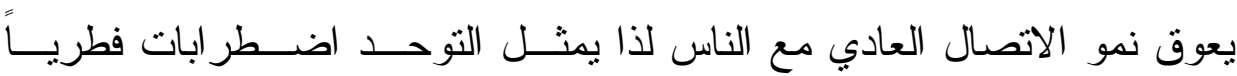
لكاتصال الوجداني.

كما تتخذ هذه النظرية وجهة نظر وهي أنه يرى الباحثين و المهتمين بذلك

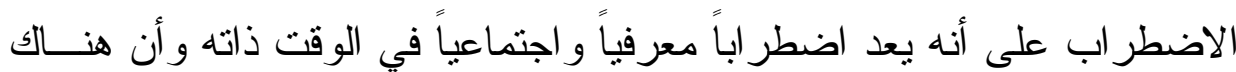

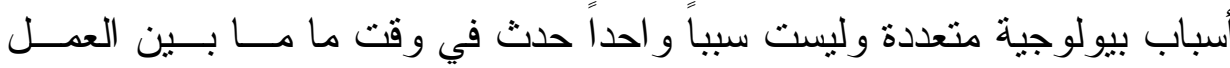

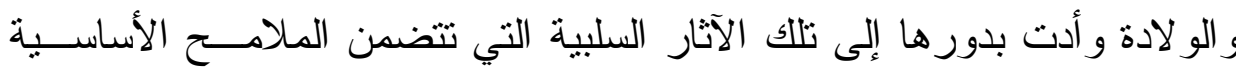

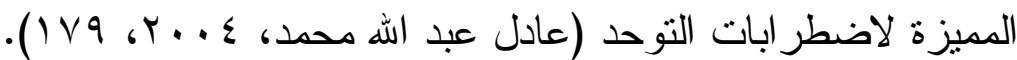

\section{علاج التوحد:}

تعد اضطر ابات التو اصل لدى الطفل التوحدي من الاضطر ابات المركبــة و الأسـاسية التي تؤثز بدور ها في ظهــور اضــطر ابات أخــرى مثنـل التفاعـلـل الاجتماعي الذي يتأثر مباشرة باكتساب اللغة، ويعاني هؤلاء من مشكلات لفظية

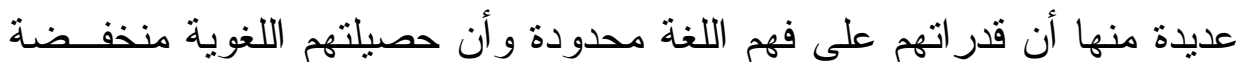
و أنهم يعانون من مشكلات في التعبير عن مـشـاعر هم و انفعـالاتهم لــذا فــان محاو لات التدخل العلاجي من خلال وضع أسلوب تدريب أو تعليم مهار ات بديلة 
لهؤلاء الأطفال يعد بمثابة إمداد هؤلاء الأطفال بحصيلة لغوية جديدة تـساعدهم في تعلم أتنكال بديلة للاتصال.

فمهما كانت طرق العلاج الطبي للتوحد فعالة فإن دور العلاج التربوي لا

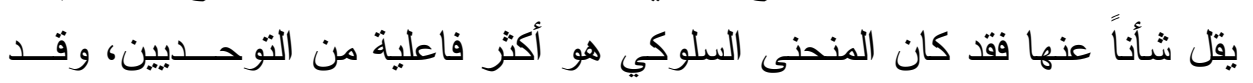

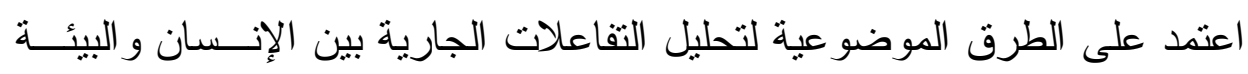

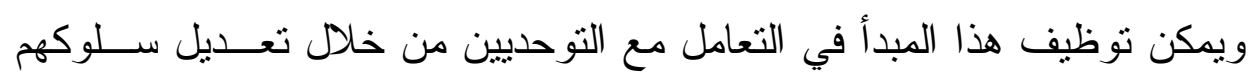

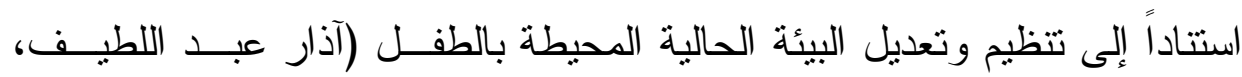

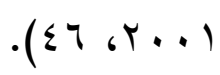

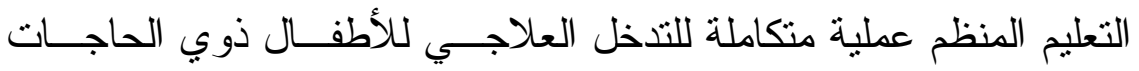

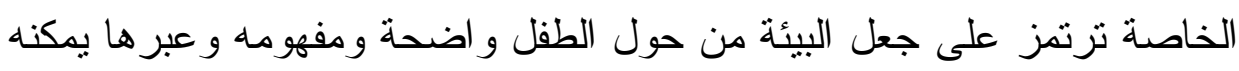

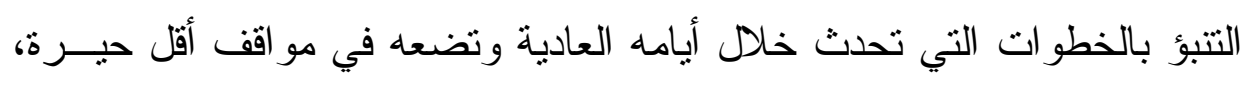

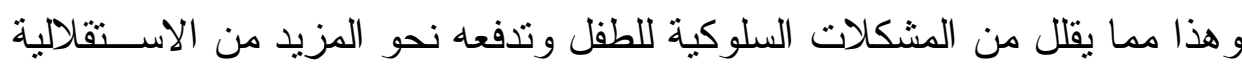

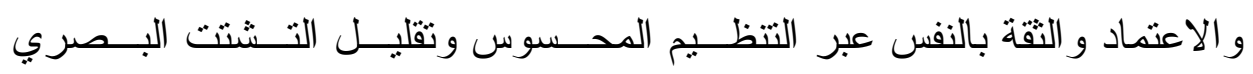

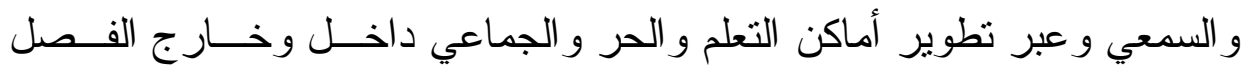

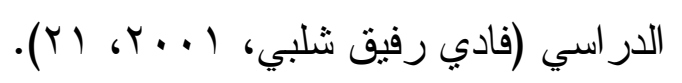

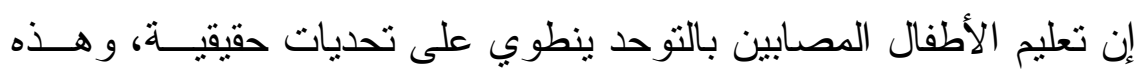

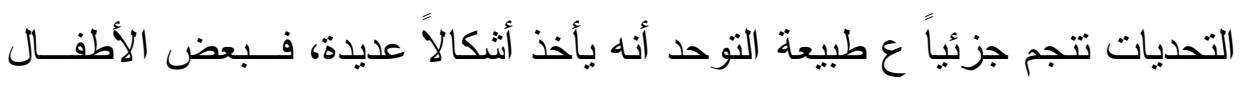

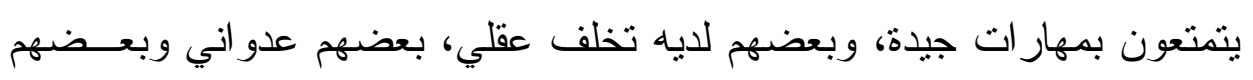

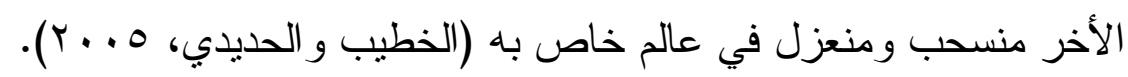

هناك العديد من العلاجات التي تنتهدف فئة الأطفال التوحديين و التـي لا لإيل

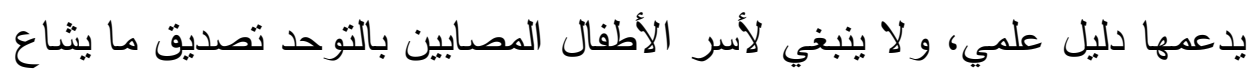

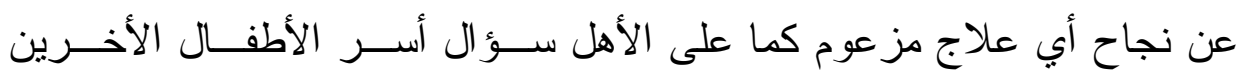

r المجلد الرابع


المصابين بالتوحد عن تجاربهم مع العلاجات الأخرى وينبغي أيضاً متابعة أخــر

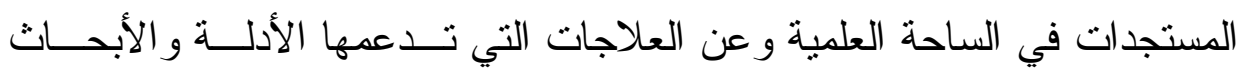
العلمية كما تجب استثارة الخبر اءو و المختصين دائماً و أبداً.

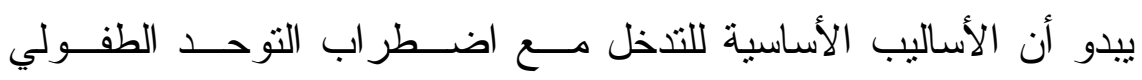

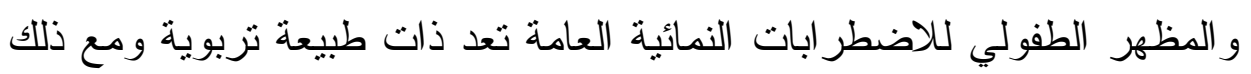

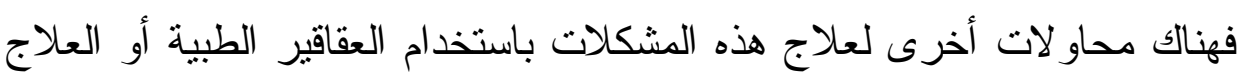

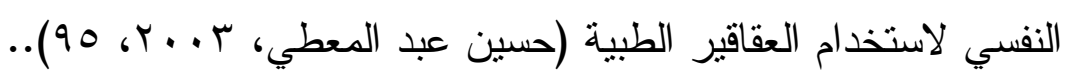

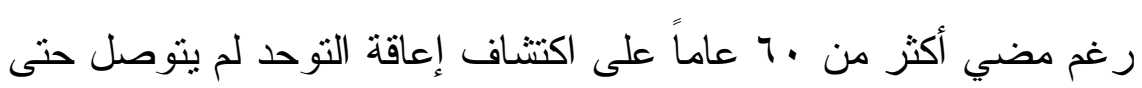

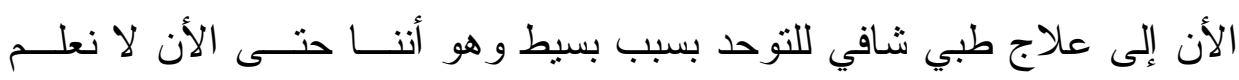

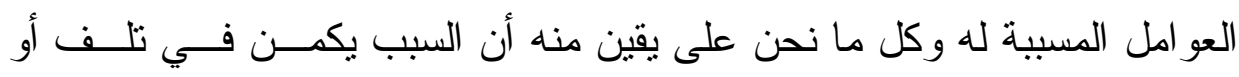

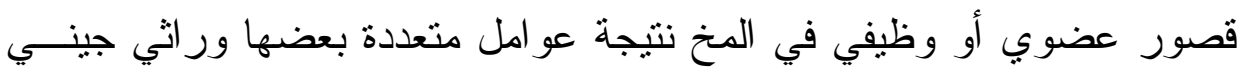

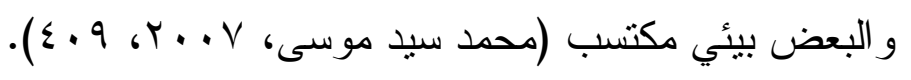




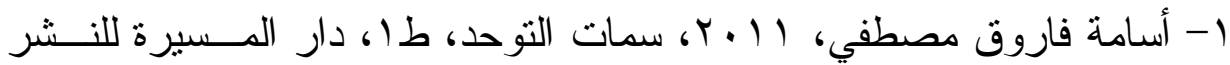

$$
\text { و التوزيع و الطباعة، عمان، الأردن. }
$$

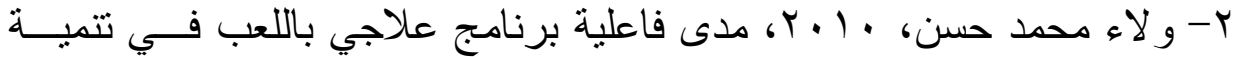

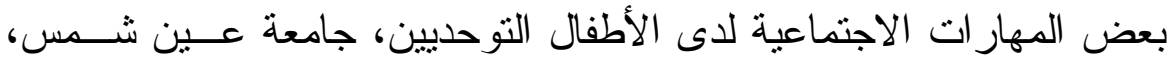

معهد الدر اسات العليا للطفولة.

r- إبر اهيم محمود بدر ، ع ...ب، الطفل التوحدي: تشخيصه و علاجــه، مكتبــة

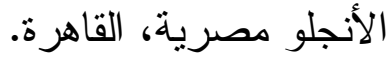

ع- عبد العزيز السيد الثخص، و99 19، اضطر ابات النطــق و الكــلام، شــركة الصفات الذهنية المحدودة، الرياض، المملكة العربية السعودية.

0- لينا عمر صديق، ؟ + . ץ، فاعلية برنامج مقتر ح في تتمية مهار ات التو اصل

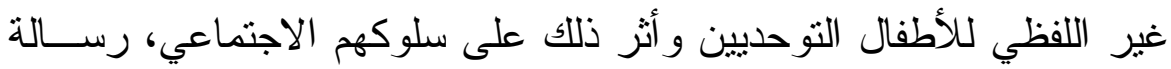
دكتور اه غير منشورة، الجامعة الأردنية، عمان، الأردن.

צ- محمد علي كامل، O. . T، التدخل المبكر ومواجهة اضــطر ابات التوحـد،

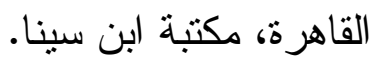

V- رضا عبد الستار رجب عبده كثك، V . . Y، فاعلية برنامج تدريبي بنظــام

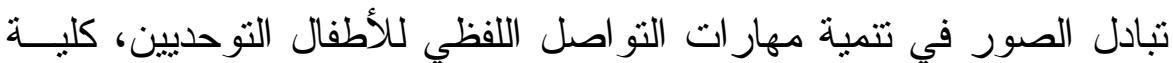

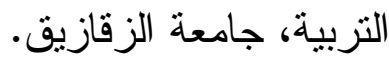

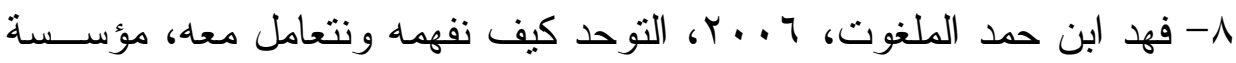

الملك خالد الخيرية، الرياض.

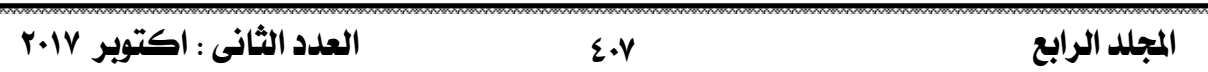


9- عادل عبد الله محمد، r . . r، الأطفال التوحسيين: دراســات تشخيـصية وبر امجية، دار الرشاد، القاهرة.

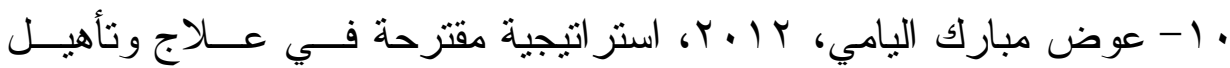

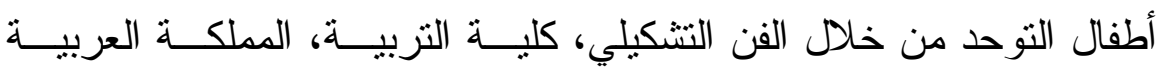

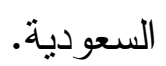

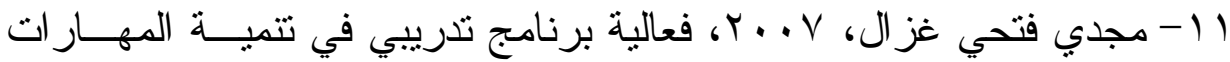
الاجتماعية لاى عبنة من الأطفال التوحديين في مدينة عمان، كليجة كلية التربية،

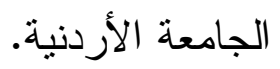

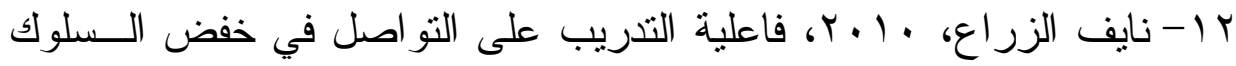

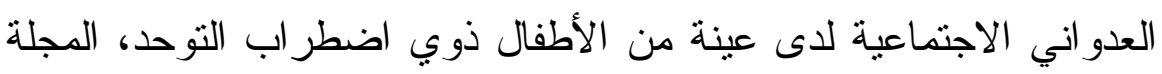

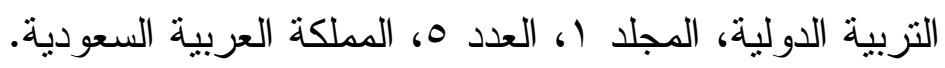
r ا - وفاء الثامي، ؟ . . r، سمات التوحد وتطور ها وكيفية التعامل معها، مركز

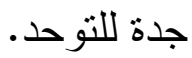

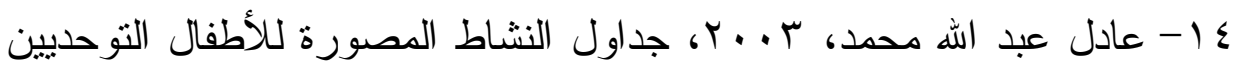

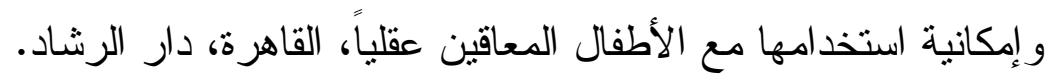
10- عمر بن الخطاب خليـل، ؟991، خــصائص أداء الأطفــال المـــابين

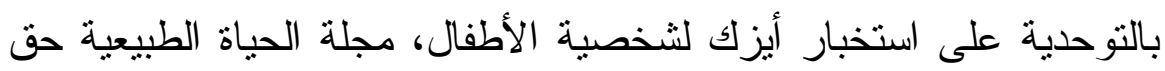

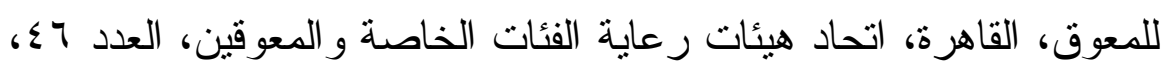
السنة الر ابعة عشر . 


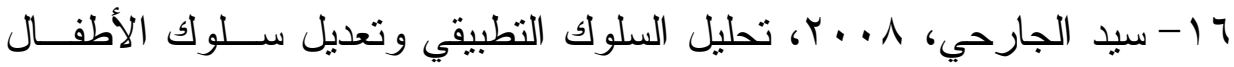

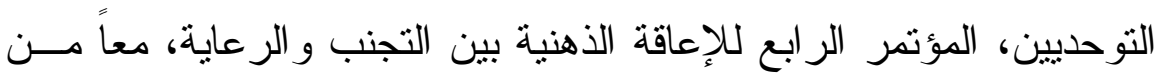

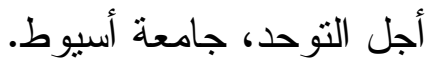

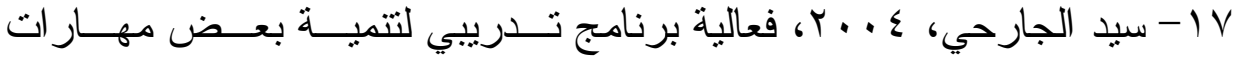

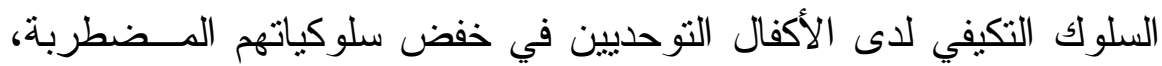
رسالة ماجستير غير منشورة، جامعة عين شمس، كلية التربية. 11 - قحطان أحمد الظاهر، 9 . . Y، التوحد، الأردن، دار و وائل للنشر.

9 19- عبد الرحيم بخيت، 999 1، الطفل التوحدي الذاتي الاجتــراري: القيــاس

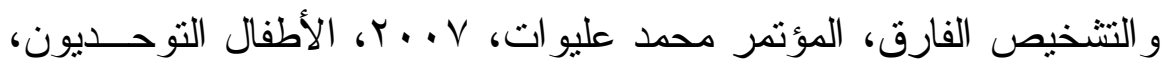
طץ، الأردن، دار البازوري.

•r- عثمان لبيب فر اج، 997 1، سيكولوجية التوحد الاجترار ، النشرة الدوريـــة لاتحاد هيئات رعاية الفئات الخاصة و المعوقين، العدد ب؟؛، القاهرة.

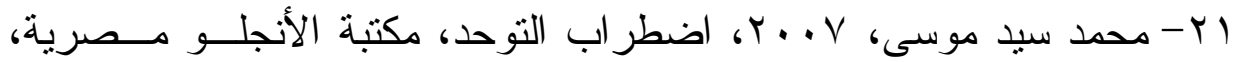

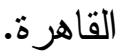

ץ ب- نيفين حسين عبد اله، فاعلية برنامج إرشادي لتتمية مهارات النو اصل لدى الأطفال التوحديين، رسالة ماجستير، كلية رياض الأطفال، جامعة القاهرة.

23- Degli Espinosa, Francesca, 2011, Verbal behavior development for children with autism, Thesis Ph.D, University of Southampton.

24- Francesca Happe 1994, Autism, an introduction to psychological theory, published by UCL press.

r. المجلد الرابع


25- Tong Breton, Bissell, p. 2004, A new Screening Questionnaire for the Assessment of autism, $9^{\text {th }}$ word congress international Association for the scientific study of Mental Deficiency, $5^{\text {th }}-9^{\text {th }}$ August, 17.

26- Nathaly Buhaghiar, L. 2005, Therapists Experience of Treating preschool Autism Children, paper in conference Autism: http://www.Autism99.org.

27- Heiman, Kari L. 2012: Treatment of autism: A review of the literature, Psy.D, California Institute of Integral Studies, United States.

28- Carter, Cynthia 2000: Using choice with interactive play to increase language skills in children with autism. A dissertation submitted in partial satisfaction of the requirement for the degree of doctor of philosophy in education, university of California, Santa Barbara. 